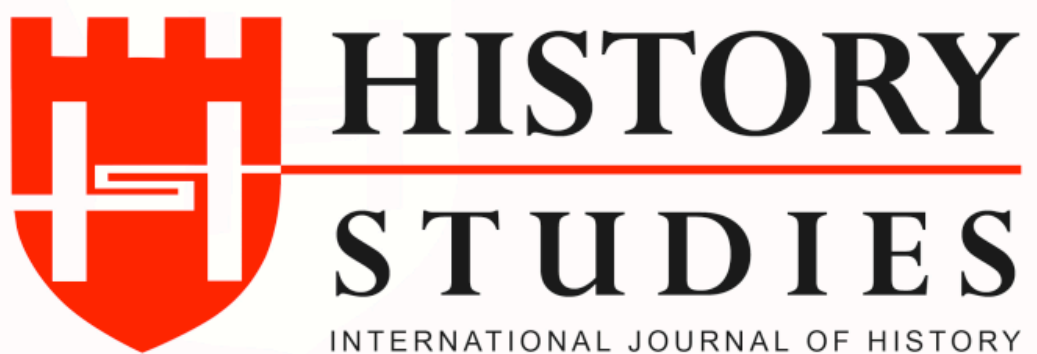

ISSN: 1309 4173 (Unline) 1309 - 4688 (Irint)

Volume 12 Issue 1, February 2020

DOI Number: 10.9737/hist.2020.829

Araştırma Makalesi

Makalenin Geliş Tarihi: 05.12.2019 Kabul Tarihi: 08.01.2020

Atıf Künyesi: Ü. Gülsüm Polat, “Cepheden Haber Var: Edmund Candler ve Mezopotamya Seferi (1916-1918)", History Studies, 12/1, Şubat 2020, s. 255-283.

\title{
Cepheden Haber Var: Edmund Candler ve Mezopotamya Seferi (1916-1918)
}

News From The Front: Edmund Candler and Mesopotamia Campaign (1916-1918)

\author{
Doç. Dr. Ü. Gülsüm Polat \\ ORCID No: 0000-0003-0048-8467 \\ Kütahya Dumlupınar Üniversitesi
}

$\ddot{O z}$

I. Dünya Savaşı sırasında orduların mobilizasyonu, sevk ve harekatın işleyişi basının işlediği konulardan olmuştur. Bu haberlerde sivil halkın olan bitenden haberdar olması belirli biçimlerde kısıtlanmış ya da karartılmıştır. Sansür uygulamaları hemen her ülkede birbirinden farklı şekilde yürütülürken İngiliz savaş basını ve bu bağlamda The Times okuyucu kitlesinin beklentisini karşılayacak haberleri ilgili kısıtlamaların dışına -çoğu kez- çıkmadan vermiştir. Savaş muhabirlerinin cephenin yıkıcı manzaralarını sivillere, gazete merkezlerine tüm çılaklığıyla aktarması her ne kadar mümkün değilse de 1915 sonundan itibaren muhabirlerin cephe haberleri gazetelerde yer almaya başlamıştır. Bunlardan birisi olan ve Britanya İmparatorluğu'nun doğu hakkında oldukça tecrübeli bir isim olarak çeşitli şekillerde hizmetinde bulunan Edmund Candler'in The Times gazetesinde neşrettiği ve 1916 başı ile 1918 Mayısı arasını kapsayan yazıları bu çalışmada incelenmektedir. Candler'in Hint Seferi kuvvetleri ile yaşadığı tecrübe Osmanlı Devleti'nin Irak harekatının en kritik muharebeleri ve askeri gelişmelerini de kapsadığı için önemlidir. Bu anlamda çalıșma hem İngiltere'nin savaş basını ve uygulamaları ile tespitleri hem de Kut zaferini de içine alan Irak'taki İngiliz-Osmanlı mücadelesinin seyrini ele alarak değerlendirmeye tabi tutmaktadır. $\mathrm{Bu}$ bağlamda çalı̧̧manın ana kaynağını dönemin İngiliz basını, başta The Times gazetesi, Edmund Candler'in hatıratı, diğer telif-tetkik eserler oluşturmaktadır.

Anahtar Kelimeler: Edmund Candler, Mezopotamya Seferber Kuvvetleri, İngiliz basını, The Times

Abstract: The mobilization, dispatch and the running of the campaign of the armies were the subjects that covered the press during the First World War. In these news reports, the information that is conveyed to the civil population about the war was restricted or obscured in certain ways. While censorship practices applied differently almost in each country, English war press and The Times usually- reported the news which would satisfy the expectations of the audience without acting against the related restrictions. Although it is not possible to convey the devastating scenes of the front line to the newspaper agencies by the war correspondents, the news of the front started to cover the newspapers from the end of 1915. The reports which were published in The Times and covered the period between the beginning of 1916 and the May of 1918 by Edmund Candler who was one of these correspondents and served to British Empire in various ways as an experienced person about the east were examined in this research. Candler's experience with the forces of the Indian Campaign is important since it covers the most critical combats and military developments of the Ottoman Empire in the Iraq campaign. In this sense, the research evaluates both the war media and practices of England with findings and the course of the battle of English-Ottoman in Iraq which includes the Kut victory. In this context, the main sources of the research consist of English press, The Times newspaper, memoirs of Edmund Candler and other compilation-research works.

Keywords: Edmund Candler, Mesopotamia Mobilized Forces, English Press, The Times 
Giriş:

I. Dünya Savaşı, benzeri o güne kadar görülmemiş çapta geniş bir askeri harekattı. Askeri açıdan geniş olması diğer bütün yönlerinin de benzer özellikte önceki savaşlardan ya daha büyük çaplı ya da eşi görülmemiş bir yapıya dönüşmesine neden olacaktı. Bu durum savaşın toplumlara ulaştırılmasında da farklılık anlamına geliyordu. Niall Ferguson'un ifadesiyle I. Dünya Savaşı bir medya savaşıydı. Savaşların önceden de gazetelere konu olduğu görülmüştü. Özellikle 19. Yüzyılın ikinci yarısında gelişen elektronik, telgraf ve fotoğraf teknolojisi sayesinde okuyucular Kırım Savaşı (1853-1856), Amerikan İç Savaşı (1861-1865) ve FransaPrusya Savaşlarına (1870-1871) dair detayları gazetelerde okuyabilmişti ${ }^{1}$. Ancak basın, savaş silahı olarak ilk defa I. Dünya Savaşında kullanılmışıı ${ }^{2}$. Savaş cephelerde tüm yıldırıcılığıyla devam ederken, anavatandakilerin olup biteni bilmeleri önünde dozu iyi ayarlanmış engeller yani sansür uygulamaları vardı. Savaşan ülkelerin basın sansürünün dozunun farklı olduğu vurgusunu açıklamak için ülkelerin uygulama farklarını belirtmekte fayda vardır. Osmanlı basınındaki sansür resmi tebligatların yayınlanmasına izin verilen haberlerin dışına çıkılamayacak kadar katıydı ${ }^{3}$. İngiliz savaş basınının da sansürden uzak olduğunu düşünmek yanlış olacaktır. Lloyd George 1917'de Manchester Guardian'dan C.P. Scott'a şunu söylemişti: "Insanlar gerçekleri bilse, savaş yarın durur. Ama haliyle bilmiyorlar ve bilemezler.

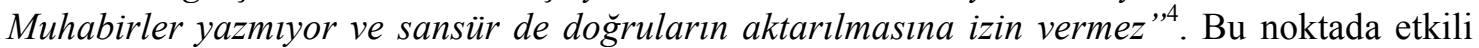
olan İngiliz propaganda sistemini göz ardı etmek imkansızdır. Daha savaşın başında Alman propagandasının inanılmaz derecede hızla ve etkili biçimde genişlediğinin farkına varan İngiliz karar alıcıları Lloyd George'un uyarısı ile harekete geçecekler ve Başbakan Asquith, yakın arkadaşı Charles Masterman'1 davet ederek bir düzenleme yapacaklardı. İsmi Wellington House olan bu büro İngiltere'nin savaşını destekleyecek ve İngiliz gazetelerine girmesi muhtemel sakıncalı telgrafların önüne geçecekti ${ }^{5}$. Wellington House'un sürüme soktuğu propaganda dokümanları arasında kitaplar, resmi yayınlar, bakanların konuşmaları ya da Kralın mesajları olacaktı. Bu propaganda malzemeleri dünyanın çok çeşitli ülkelere ulaştırılacaktı ${ }^{6}$.

1914’te İngiliz, Fransız ve Amerikan gazete okuyucuları heyecanlı ve açık bir dile sahip savaş raporları okumayı umuyorlardı. Zira 19.yüzyılın ikinci yarısından sonra haberin aktarımını kolaylaştıran telgraf ve fotoğraf gibi teknolojilerde görülen artış bu yüzyılın harplerinde savaş haberciliğini etkileyen bir faktör oldu. Kırım Harbi, Amerikan Sivil Savaşı İç Savaş1- (1861-1865), ve Fransa-Prusya Harbi (1870-1871) gibi savaşlarda bağımsız profesyonel muhabirler cepheden haberler ulaştırmışlardı. 19. Yüzyıl sonunda The Times'dan William Howard Russell (1821-1907) ya da Daily Mail'den Archibald Forbes (1838-1900) gibi isimler maceracı, gerçekleri yazan bir gazetecilik geleneği yaratmayı başarmışlardı. Ancak bu

\footnotetext{
${ }^{1}$ Tim Luckhurst, War Correspondents, in: 1914-1918-online. International Encyclopedia of the First World War, ed. by Ute Daniel, Peter Gatrell, Oliver Janz, Heather Jones, Jennifer Keene, Alan Kramer, and Bill Nasson, issued by Freie Universität Berlin, 2016-03-15

${ }^{2}$ Niall Ferguson, Hazin Savaş 1914-1918, (Çev. Nurettin ElHuseyni), YKY Yay., İstanbul 2015, s. 272.

${ }^{3}$ Erol Köroğlu, "Propaganda mı, Kültür Savaşı mı? Birinci Dünya Savaşı Dönemi Türk Edebiyatında Cihat, İslam ve Milliyetçilik", Âb-1 Hayat-1 Aramak Gönül Tekin'e Armağan, (Yay. Haz. Ozan Kolbaş, Orçun Üçer), Yeditepe Yay., İstanbul 2018, s. 451- 452. Ayrıca bkz: Erol Köroğlu, Türk Edebiyatı ve Birinci Dünya Savaşı (1914-1918) Propagandadan Milli Kimlik İnşasına, İletişim Yay., İstanbul 2004.

${ }^{4}$ Philip Knightley, First Casualty: The War Correspondent as Hero and Myth-Maker from the Crimea to Iraq, Johns Hopkins University Press 2004, s. 109; Ferguson, Hazin Savaş 1914-1918, s. 273.

${ }^{5}$ Michael Sanders and Philip M. Taylor, British Propaganda during the First World War 1914-1918, Palgrave Macmillan, London 1982, s. 38-40.

${ }^{6}$ Gary S. Messinger, British Propaganda and the State in the First World War, Manchester University Press, Manchester 1992, s. 75-79.
} 
durum I. Dünya Savaşı'nın başlaması ile yürürlüğe giren bir dizi kanunla tamamen değişecekti ${ }^{7}$.

Yine de cephede olan bitenin tamamen kurgusal bir şekilde karartıldığını düşünmek İngiliz savaş basınını yanlış yorumlamak ve değerlendirmek olacaktır. Öyle ki, cephe olaylarının haber oluş biçiminde gerçeklikten kopuşlara fazla rastlanmaz. Daha savaşın başında Çanakkale'de batan İngiliz zırhlılarının haberlerini İngiliz okuyucu gün gün takip etmiştir ${ }^{8}$. İngiliz basınında savaşa dair haberlerde ölüm, yaralı, kayıp uğranılan zayiatlara dair verilen bilgilerin savaşın gerçekliği ile uyumlu olması basın üzerinde sansür olmadığı anlamına gelmemektedir. Çanakkale Harekatı haricinde diğer cephelerde de haberlerin gazete sütunlarına taşınmasında Lloyd George'un C.P. Scott'a söylediği türden çok daha hassas bir kontrol yönteminin uygulandığı sonradan yapılan çalışmalar ve haberlerin içeriğine nüfuz edildiğinde anlaşılabilmektedir'. Bu noktada cephelerdeki İngiliz muhabirleri kendilerine verilen izin çerçevesinde haberler geçtiler. Eski bir Albay olan Charles á Court Repington ya da yazar ve I. Dünya Savaşı sırasında cephede bulunan az sayıda kadından biri olan Harriet Chalmers Adams (1875-1935) ve Alice Schalek (1874-1956) gibi isimler bu zorlu göreve talip oldular. Tıpk1 onlar gibi Edmund Candler de, Osmanlı Devleti ile İngiltere'nin en sert çatışmalarını yaşadığı Basra Harekâtının ardından gelen Kûtü'l Amâre ve İngilizlerin Bağdat'a girişi ile neticelenen süreci gazetesine yazdi.

Yazar, öğretmen ve seyyah olan Edmund Candler (1874-1926) döneminin pek çok etkili ismi gibi Cambridge'de eğitim almıştı. 1895'de Emmanuel College'den mezun olmuş ve kariyerini Hindistan'da inşa etmişti. İngiliz doğusunda önemli tecrübe edinmişti. Birçok roman yazmış ve bir kısmını yirmi yıl boyunca Daily Mail ve Pioneer gibi gazetelerde neşretmişti. Bir elini Tibet seyahati sırasında 1904'te kaybetmiş̧i. Candler'in I. Dünya Savaşı'ndaki kariyeri yar1-resmi bir hüviyetle Fransa'da savaş muhabiri olarak başlayıp, Mezopotamya Hindistan Seferi Kuvvetleri resmi gözlemcisi [eye witness with the Indian Expeditionary Force in Mesopotamia] olarak devam etmişti. Savaştan sonra Penjap Hükümeti nezdinde Halkla ilişkiler direktörü olarak görevlendirecekti. 1919-1921 yılları arasında görev yaptı̆̆ı bu pozisyona I. Dünya Harbinde edindiği tecrübe nedeniyle getirilecekti ${ }^{10}$.

Söz konusu yazıların içeriği konusunda tespitleri sıralamadan evvel Basra'da başlatılan harekatın kırılma noktalarını şu şekilde belirlemek faydalıdır: 1914'ün 1 Kasımında yani Osmanlı Devleti'nin savaşa girdiğinin kabul edilmesiyle başlatılan Hint Birliklerinin çıkarma harekat1, bu birliklerim 26 Eylül 1915'te Kûtü'l Amâre'yi işgali ve Bağdat yönünde gerçekleştirilen Osmanlı VI. Ordusu karşısındaki ileri hareketler ve geri çekilme, İngiliz birliklerinin Kûtü'l Amâre'de muhasara altına alınmaları ve Nisan 1916'da teslimiyet. Buraya kadarki gelişmeler İngiliz birliklerinin Mezopotamya seferinin olumsuz etkilerine karşılık

\footnotetext{
${ }^{7}$ Luckhurst, "War Correspondents", International Encyclopedia of the First World War.

8 Diğer pek çok örnek içerisinden Goliath zırhlısının torpillenmesine dair haberlere bakılabilir: Our Naval Correspondent, "Naval Gains and Losses, The Fate of the Goliath", The Times, 14 Mayıs 1915. Ayrica resmi açıklamada 500 kişinin hayatını kaybettiği bildiriliyordu. "Goliath Lost in the Straits, Torpeded by Turks at Night", The Times, 14 Mayıs 1915.

${ }^{9} \mathrm{Bu}$ konudaki argümanımızı güçlendirecek tespitler için bkz: Ü. Gülsüm Polat, "Başarılı Savunmadan Esarete: İngiliz Basınında Kûtü'l Amâre Kuşatması”, 100. Yılında Uluslararası Băgdat (Medînetü's Selâm) ve Kûtü'l Amâre Sempozyumu, İstanbul, 20-22 Aralık 2017.(Basım aşamasında), General Townshend'ın ve birliğinin esir düşmesi sonrası İngiltere'de haberlerin tonuna dikkat edilmesine dair bir uyarı ile başlayan gelişmeler için bkz: Ü. Gülsüm Polat, Esir Kut Komutanı Townshend'ın İstanbul'a Getirilişi ve İngiliz Savaş Basınına Müdahale", 100. Yılında I. Dünya Savaşı Uluslararası Sempozyumu, 03-05 Kasım 2014, Budapest/Macaristan. (Bildiri metini basılmıştır: Akademik Ortadoğu, C. 9, Say1: 2, s. 131-145.

${ }^{10}$ Sharmishtha Roy Chowdhury, The First World War, Anticolonialism and Imperial Authority in British India, Routledge, London 2019, s. 80.
} 
gelirken teslimiyetin ardından buradaki Türk birliklerinin İran içlerine yönlendirilmesi nedeniyle İngiliz birliklerinin yeni kuvvetlerle harekete devam etmeleri ile Bağdat'ın düşmesi (1917 Martında), Musul yönünde ilerleyişin devamı ve mütarekeye kadar ileri harekatın sürmesi şeklinde sürmüştür.

\section{İngiliz Basınında Mezopotamya Harekatı}

İngiliz basınında cepheden haberlerin yer almaya başlamasının yani savaş muhabiri olarak tasvir edilebilecek haberlerin en erken örneğinin Kırım Harbi olduğu anlaşılmaktadır. Sonraki y1llarda harp muhabirlerinin tecrübesi Lord Kitchener'ın Hartum seferinde (1898) yeniden önemli bir merhaleden geçti. Ancak savaş muhabirlerinden ve muhabirlerin yaptığı işten çok memnun olmayan Lord Kitchener savaş raporlarına yansıması muhtemel gözlemlere izin vermedi. Yirminci yüzyılın ilk on yılında, savaş muhabiri orduya küçük seferlerde eşlik edebilirdi, ancak bunun belli kuralları vardı. Bu katılımcılar asker arasındaki moral, birlikler için kötü koşulların ya da yerel nüfusa yönelik zulüm gibi olumsuz koşulları rapor etmeyeceklerdi ${ }^{11}$.

I. Dünya Savaşına ve bu bağlamda Mezopotamya Harekâtına bakıldığında İngiliz birliklerinin ilerleyişinde sorun yaşanmadığına dair haberlerin çoğunlukta olduğu görülmektedir. Gerçekten de 1914 Kasımından itibaren İngiliz birliklerinin ilerleyişini ciddi anlamda sekteye uğratacak herhangi bir gelişme yaşanmamıştı. Ancak 1915 Kasımında Selmanıpak'da Türk ve İngiliz kuvvetleri arasındaki muharebenin ardından da Türk birliklerinin takip harekâtı neticesinde Delabiha Muharebesi'nde Türk kuvvetleri büyük direniş göstermişti. Bundan sonraki günlerde İngiliz birlikleri Kut'a çekilmişlerdi ${ }^{12}$. The Times gazetesinin farklı nüshalarında ilk evreye ait çok sayıda haber göze çarpar. Bu haberler diğer haberlere göre nicelik olarak fazladır.

Aralık 1915'ten yani İngiliz birliklerinin Kut'ta savunma pozisyonuna geçmesinden sonra çıkan haberlerde de muharebelerin oluş şekli, kayıplar ile ilgili detaylar verilmeye devam edilmiştir. Zira Kut'tan çıkış için İngiliz kuvvetleri birkaç defa yarma harekâtı için uğraşmışlarsa da bunu gerçekleştirememişlerdi. Bazı haberlerde ise ölü, yaralı, esir kısacası zayiatlarla ilgili Türk tarafının verdiği sayılara itimat edilmemesi istenmiștir. Atamalara da haberler arasında yer verildiği görülmektedir. Von Der Goltz Paşa'nın atanması bu bağlamda yer bulan haberlerdendi ${ }^{13}$. İngiliz birliklerine General Aylmer kumandasında ulaştırılmaya çalışılan yardım, Hindistan'daki İngiliz genel valiliği ile diğer yönetim birimleri arasındaki görüş farklılıkları basında zaman zaman konu olmaktaydı. Sevk, yönetim, organizasyon konusundaki eksikliklerle ilgili haberler General Aylmer'in yardım harekâtı girişiminin başarısızlığa uğradığı günlerde görülmeye başlanmıştır ${ }^{14}$.

\footnotetext{
${ }^{11}$ Brian Best, Reporting from the Front. War Reporters during the Great War, Pen\&Sword, London 2014, in prologue [sunuş yazısı içinde]

${ }^{12}$ Gelişmeleri tarafların komuta düzeyinin hatıralarından takip etmek istendiğinde Townshend'ın anlatımı öne çıkmaktadır: Charles V.F.Townshend, My Campaign in Mesopotamia, Thornton Butterworth Limited, London, 1920. Türkçeye çevrilmiştir: Mezopotamya Seferim, Kurnâ, Kûtülamare ve Selamnıpâk Muharebeleri, (Çev. Gürol Koca), Türkiye İş Bankası Yay., İstanbul 2012. Türk tarafının savaş sonrası bir komisyon tarafından askeri tarihin ortaya çıkması için yazılmasına ön ayak olduğu eser ise iki ciltlik Birinci Dünya Harbi'nde Türk Harbi serisinden Irak-İran Cephesi (Genelkurmay ATASE Başkanlığı Yay., Ankara 1979) isimli çalışmadır.

13 "Von der Goltz to go to Mesopotamia", The Times, 7 Aralık 1915.

14 Türk kuvvetleri ile General Aylmer kuvvetleri arasındaki muharebeler Ocak 1916'da yaşanacaktı. Türkler ağır kayıplar vermesine rağmen Aylmer'in misyonu da başarısız olacaktı. Süreçleri askeri açıdan en detaylı anlatan kaynak Birinci Dünya Harbinde Türk Harbi Irak- Iran Cephesi, 3. Cilt, 1. Kısım, Genelkurmay Basım Evi, Ankara 1979.
} 
Kut ile ilgili tüm tecrübelerini daha sonra yayınlayan Edmund Candler'in hatıratından anlaşıldığına göre Royal George kruvazörü ile 5 Aralık 1915'te Marsilya'dan hareket ederek Mezopotamya'ya ulaşmışt1 ${ }^{15}$. Candler'den gazeteye yazdığı haberlerde Mezopotamya Seferi Kuvvetlerinin İngiliz Basın Temsilcisi [the representative of the British Press with the Expeditionary Force in Mesopotamia $]^{16}$ olarak bahsedilmektedir. ${ }^{17}$. Edmund Candler'in bölgeye ulaştıktan kısa zaman sonra yaşananlara dair verdiği bilgilerin haber olmaya başladığ görülmektedir ${ }^{18}$. Candler'in Ocak 1915 'te verdiği bilgilerin yazının sonunda ya da başında kaynak olarak kendi adının verilmesine dair örnekler görülmektedir. Ancak asıl muhabir olarak kendisi tarafından verilen haberlerin düzenli sayılabilecek aralıklarla 1916 Ocaktan sonra başladığı görülmektedir. Basra'dan 10 Ocak'ta yazdığı, gazetede 12 Ocak 1916'da yayınlanan haberinde General Aylmer'in yardım götüren kuvvetinin ilerleyişinden söz edilmekteydi ${ }^{19}$. Bundan sonra Candler savaşın sonunda İngiliz birliklerinin Musul'a girişine kadar The Times'da yazılarını yayınladı. Bu kapsamda 90'a yakın yazı yayınladı. (Haber başlıkları: Ek 1) Bir seri teşkil eden bu haberlerin ardından bazı haberlerde de Candler'in ismine rastlanmıştır. Kendi adıyla çıkan bir diğer habere 1922 yılında rastlanmaktadır: "Holy City of the Shiah. Medieval Life in the Desert. The Problems of Mesopotamia. A 'Sacrilegious Regime', başlı̆̆ını taşımaktadır. Bu yazısının bölgeden bildirilmediği anlaşılmaktadır.

HISTORY STUDIES

259

Volume 12

Issue 1

February 2020

\section{Candler'in Hatıratının Analizi ve Haber içerikleri ile Mukayesesi}

Candler'in kitabının birinci cildi Fav'daki çıkartmadan Kut'taki teslimiyete kadar olan süreci işlemektedir. Birinci cildin girişinde tüm süreci kısaca özetlediği görülmektedir. Candler, gelişmeleri 16 Ekim 1914'te Mezopotamya Seferi kuvvetlerinin [The Mesopotamian Expeditionary Force] Hindistan'dan ayrılması ve 18 Ekim'de Bahreyn'e çıkmasıyla anlatmaya başlamaktadır. Candler'in hatıratının birinci cildinde Fav'a Mezopotamya birliklerinin çıkarılmasından sonra önemli dönüm noktalarını öne çıkarıldığ 1 görülmektedir. Bu ilerleyişin arka planına dair zorlukların farkında olduklarını anlatan Candler 2 Kasım 1914'te Başbakan Asquity'in Parlamento konuşmasında Bağdat'ta belirli derecede yakın olduklarını söylediğini ancak Alman basınında yer bulan kimi yazılarda iaşe ikmalinin kolay olmadığının vurgulanmasının şüphelerini arttırdığına değinmekteydi. Savaş dönemi İngiltere'sinde Almanların yıkıcı ve acımasız düşman tarifi için kullanılan Hun ifadesini kullanan Candler, "Bağdat' istiyorduk. Şehir dayanılmaz bir çoban yıldızıydı. Bu Gelibolu'yu ateşleyebilirdi. Bu şehri tutmak dalgalanan Doğu'yu yatıştırabilirdi. Iran, Afganistan sınırındaki kabileler daha sakin bir tarafsızlığa ya da dostluğa evirilebilirdi Hindistan'da bozulan iç yönetim düzelebilirdi." ifadeleriyle harekatın amacını açıklamaktadır ${ }^{20}$. Fav'dan Tizpon'a kadar geçen kısım: Fav'a çıkış ile ilgili İngilizleri azımsanmayacak bir Türk kuvvetinin karşıladığı anlaşılmaktadır. Türklerin 5000 asker 12 makinalı tüfekle karşıladıklarını belirtmektedir. Ancak başarılı olan İngiliz Hint birliklerinin Aralık 1914'te Basra'yı ele geçirdiğini son Osmanlı valisi Suphi Bey’i ve 1084 esirle ve dört makinalı tüfekle ele geçirdiklerini belirtmektedir ${ }^{21}$. Çıkarmadan sonra ileri harekât esnasında yaşanan tüm çatışmaları, silah türlerini, birlikleri konuşlanma biçimlerini anlatarak devam etmektedir. İngiliz deniz kuvvetlerinin parçalarını da ismiyle anan Candler, nehirdeki İngiliz donanma desteğini bir hayli

\footnotetext{
15 Edmund Candler, Long Road to Baghdad, Vol. I-II, Cassell and Company Ltd., London, New York, Toronto 1919, s. 25-27.

${ }^{16}$ Yukarıda belirttiğimiz "eye witness with the Indian Expeditionary force in Mesopotamia" ile hemen hemen ayn1 anlama gelmektedir.

17 "Plundering Arab Horsemen", The Times, 21 Şubat 1916.

18 "The March on Kut",The Times, 12 Ocak 1916.

19 “A Most Gallant Attack. Whole Turkish Battalion Accounted For", The Times, 12 Ocak 1916.

${ }^{20}$ Candler, Long Road to Baghdad, Vol. I, s. 3 vd.

${ }^{21}$ Candler, Long Road to Baghdad, Vol. I, s.11.
} 
önemsemektedir. Stratejik ve politik nedenlerden ötürü Kut'a ilerleme kararının alındığını Türklerin kuvvetlerini burada topladıklarının bilindiğini söylemektedir. General Delamain kumandasındaki askerlerin açlık ve susuzlukla uzun bir mesafeyi dinlenmeksizin yürüdükten sonra Türklerle giriştikleri mücadele neticesinde 14 tüfek ve 1153 esir yaklaşı 1000 ölü ile çekilmek zorunda kaldıkları anlatılmaktadır ${ }^{22}$. Böylece Kutül Ammare'yi alan Townshend'ın yıldızının daha da parladığını belirtmektedir. Kutül Ammare'nin ele geçirilmesinin Hint birliklerinin en parlak zaferi olduğu vurgulamaktadır. 17 Kasım 1915'te Tizpon'un düşüşünden 4 gün sonra General Nixon'un Savaş Bakanlığı'ndan aldığı bilgiyle Von der Goltz Paşa'nın Bağdat'tan ayrıldığı ve Anadolu'dan Irak'a 80.000 Türk askerinin ilerlediğinin öğrenildiğini belirtmektedir. Tizpon [Selmanıpak] muharebesi 6. Birliğin çatışmasıyla başlamıştı. İngilizlerin geri destekleri ile aradaki mesafenin 9 mil olmasının işleri zorlaştırdığından söz eden Candler, birliklerin Kut'a geri dönmek zorunda kaldığından söz etmektedir. Ummel Tubal'de askerlerin istirahatleri ile sabah 1şıklarıyla Türk kumandanı Nureddin'in kuvvetleri tarafından kuşatıldıklarını fark ettiklerini bu kuvvetlerin gece gelip etraflarını sardığını yazmaktadır ${ }^{23}$. Yardım birlikleri için General Melliss kumandasında bir kuvvetin Kut'a gönderildiğini ancak bu birliğin geri çağırılmak zorunda kaldığını anlatmaktadır. Yaşananların aktarımı sayesinde kuşatmayı canlandırmak mümkündür: "Sabah ışıklarıyla çok olağandışı bir manzarayla karşılaştık. Türk çadırları kuzeye ve batıya doğru kampımızı üç defa çevreleyecek biçimde kuşatmuş vaziyetteydi."

Candler, çalışmanın takdim kısmında kitabın olaylar yaşanırken yazıldığını açıklamaktadır.

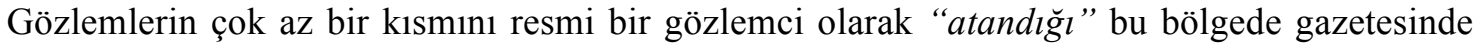
basılabildiğini anlatarak devam etmektedir. Hatıratında üçüncü bölümde Marsilya'dan 5 Aralık 1915 'te Royal George gemisiyle ayrılmasını anlatmaktadır. Aynı gemide bulunan resmi görevlilerin de dahil kimsenin nereye gidildiği konusunda net bir bilgisi olmadığını yalnızca doğu hattına gittikleri yönünde bilgilendirildiklerini, bunun anlamının ise hayli karmaşık; Selanik, Gelibolu, Mısır, Doğu Afrika, Mezopotamya gibi birbirinden çok farklı bölgelere karşılık gelebileceğini belirtmektedir. Türklerin hâlâ Kanal'a önemli bir saldırı planlandıkları beklendiğini eklemekte pek çok ihtimal içerisinde Irak'a gittiklerini düşünmediklerinden söz etmektedir. İskenderiye'ye ulaştıklarında kendilerinin yolculuğunun devam edeceğini öğrenmişlerdi ${ }^{24}$. Candler'in bu ifadelerinden gizliliğe verilen önem anlaşılmaktadır. Zira Candler'in de aynı gemide olduğu Hint birliklerinin sevkiyatının gerekli gizlilikle yapılması istenmiş olmalıdır ${ }^{25}$. Aynı gemideki Hint birliklerini kastederek "Biz" ifadesini kullanan Candler'in hatıratında kullandığı anlatım dili dönemin hatırat yazımının genelinden farklılık göstermemekte ve İngiliz savaş anlayışını ve davranışlarını yüceltmektedir. Yine de hatıratında savaşın yıkıcılığını anlattığı satırlara da rastlanmaktadır: "Yaralıların bir kısmı tüm gece dışarda kaldı. Ĕger müdahale edilseydi yaşayabilecek olanların birçoğu hayatını kaybetti. Ön siperde uzanmış vaziyette bir Kuzey İskoçyalı bulundu, yüzü mavi tebeşir rengindeydi, belinden vurulmuş, kanama yüzünden ölmüştü... karanlıkta ağlayan bir adam sesi duyuldu. 'Tanrı aşkına birisi yardım etsin boğuluyorum' diyordu. Doktor aramaya gitti ve bir ayağ l mayınla parçalanmış bir asker buldu ve onu nazikçe çekti, ${ }^{, 26}$.

\footnotetext{
${ }^{22}$ Candler, Long Road to Baghdad, Vol. I, s.19-20.

${ }^{23}$ Candler, Long Road to Baghdad, Vol. I, s. 24.

${ }^{24}$ Candler, Long Road to Baghdad, Vol. I, s. 28 vd.

${ }^{25}$ Türk makamları sürekli asker sevkiyatını takip etmiș ve düşman gücünü kestirmeye çalıșmıștır. Hint birliklerinin hareketliliğini aldıkları duyumlara istinaden bildirmişlerdir: Ü. Gülsüm Polat, Osmanlı Devleti ve İngiltere Ekseninde I. Dünya Savaşı Yıllarında Mısır, ATAM Yay., Ankara 2015, s. 44-47.

${ }^{26}$ Candler, Long Road to Baghdad, Vol. I, s. 100.
} 
Hatıratının Modern Muhabirlik başlıklı altıncı bölümünde Candler'in görevi ve bunun İngiliz birliklerinde nasıl karşılandığına dair detaylar verdiği görülmektedir. Akredite edilmiş bir muhabir olarak "eye-witness" [gözlemci] unvanı hakkında spekülasyonun arka planında diğerlerinin düşüncelerini anlamaya çalışıyor ve kendisini şöyle gördüklerini düşünüyordu: "eye-witness [gözlemci], gözlemleyen ama konuşmayan". İronik biçimde acil tıbbi yardım elemanı için de "gören fakat dokunmayan" dediklerini belirtiyordu. Candler modern savaş muhabirliği ile ilgili de açıklama yapmaktadır. Bu işi yapacak kişinin sadık, disiplinli ve sürekli kendisini geliştirmesi gerektiğini belirtmektedir. Yazdıklarının tüm kuvvetler için eğlence kaynağ1 olduğu ifadesi dikkat çekmektedir. Dahası haberlerinin içeriğine yansıyan durumu hatıratında aslında açıklamaktadır: "Mezopotamya'da süreklilik arz eden kurum ise sansür idi... dışardaki dünya ile serbestçe iletişim kurmak imkânsızdl... muhabirlerin sadece bildirimleri değil makaleleri de hayati organlarının parçalanmasıyla ortaya çıkıyor, bunlarda görülen dil kendilerine ait değildi, ăğr resmi bir el herhangi bir ayırt edici veya bireysel dokunuşu aşă̆ taşıyordu” demektedir. Ancak Candler sansürün kaçınılmaz olduğunu zira harekata dair ipucu verecek bir makalenin Türklere istihbarat çalışmalarından daha fazla yol gösterici olabileceğini düşünüyordu. Bu kısımda Mezopotamya birlikleri ile Hindistan ve Londra arasındaki iletişimin nasıl bir sansüre tabi tutulduğu da anlatılmaktaydı: "Suçlanacak olan sansür memurları değildi. Onlar uygulanan sisteme sadıktı. Resmi kurallara uygun olmayan bir yazıyı geçirselerdi daha yetkili eller tarafindan muhtemelen zaten bu yazılar uzaklaştırllırdl. Mezopotamya'dan gönderilen telgraf gönderileri Tigris (Dicle) Askeri Karargâhında sansürlenip Basra'ya gönderilmekteydi burada (Genel Karargah) yeniden sansürden geçirildikten sonra Karaçi'ye buradan bir kopyası Delhi Ordu Karargahına gönderilmekteydi. Ordu genel karargâhından verilen emir üzerine Bombay gönderileri Londra'ya Basin Merkezine göndermekte ve son olarak bu birim Londra'da Basin Bürosuna son sansür işlemi için sunmaktaydı. Ancak yazının geçtiği bu geçiş bürolarından her birisi askeri ve politik farkl yetkililer altındayd. Orijinal metinde çok az görülen çelişki yaratabilecek uygunlukla ilgili meseleler danışılmalıydı."27. Bu ifadeler sansürün nasıl uygulandığını göstermekteydi. Candler, savaşa dair bir olayı açıkça eleştirmenin mümkün olmamasına rağmen örtülü bir eleştiri olmadan bir şey yazmanın imkânsız olduğuna değiniyordu. Ülkenin sınırlarındaki halklar hakkında Arap, İranlı ya da Türkler hakkında ve genel itibariyle politik ilişkiler hakkında yazmanın imkansız olduğunu belirtiyordu. " $\mathrm{Hacl}$ William" șeklinde ifade ettiği Alman Kayzeri hakkında yazmanın doğru olmadığını zira Hintlilerin çok azının Almanların cihat hakkında fetva verdiğini bildiklerine değiniyordu. $\mathrm{Bu}$ nedenle dikkatli olmanın önemini hatırlatıyordu. Eski usul muhabirlik ile kıyaslayarak savaş muhabirlerinin yöntemini şöyle anlatıyordu: "Uzun zamandır bir şeyleri yapma girişiminden vazgeçmiştim. Göz açıp kapatıncaya kadar susturulmaya razı oldum. Eski savaş muhabiri tarzı için artık bir şey yok ve hiçbir koşul onu canlandıramaz, yine de tehlikeli bir maceradan geçen bir çeşit cesaret... atlı hücumu, gönderileri taşımak, generallerle istişare etmek, bir mızrağın nerede belli olmayan hedefi olmak, tüm dünyanın zaferini beklediği ve ona itiraz etmeye hazır olduğu bir karışım" ${ }^{28}$.

Yazar yedinci bölümde Vadi Muharebesi'ni anlatmaktadır. Buradaki çatışmaları "Mezopotamya'daki en anlaşılması güç çatışmalardan birisi" olarak tanımlamaktadır. Gazete başlıklarına kayıp ve ölülerle ilgili bilgi aktarmak mümkün değilse de ölen askerlerin üniformaları ve diğer her detayın hakkında bilgi anlamına geldiğini belirtmektedir ${ }^{29}$. Sekizinci bölümde Ümmel Hannah muharebesini anlatan Candler, 21 Ocak 1916 gecesini ayrı bir bölüm

\footnotetext{
${ }^{27}$ Candler Long Road to Baghdad, Vol. I, s. 66-67.

${ }^{28}$ Candler, Long Road to Baghdad, Vol. I, s. 69.

${ }^{29}$ Candler, Long Road to Baghdad, Vol. I, s. 81.
} 
olarak ele almaktadır. Gerçekleşen ateşkesi de anlatan Candler, bu kısımda savaşta ittifak kurulan kabilelerin güvensizliğinden söz etmektedir: "Genel olarak Araplar Türkler için savaşıyorlardı ama en güvenilmez müttefiklerdi. İslami bağları derinlerdeydi, ama onların dostlukları değişip Türkleri yağmalayabilirdi." ifadelerine yer vermekteydi. Bu kısımda Türklerin Araplara bakış açısına dair bilgiler de dikkat çekicidir. Türklerin Arapların savaş̧̧ılığını "hor gördüğ̈̈”, ateşkes için Halil Bey ile yapılan görüşmeler esnasında esirlerin değişimi için İngiliz ve Hintli askerlere karşılık olarak Arap esirlerin takasını reddettiğini onların savaştan imtina eden kaçaklar olduğunu düşündügünü yazmaktadır. Almanlardan genel olarak Hunlar olarak bahseden Candler Türkler ile Almanları mukayese ederek, Türklerin "nezaket ve kahramanlikta onlardan inanılmaz derecede üstün olduğunu” belirtmektedirler. Candler, Türklerin Kızılhaç hastanesine ve yaralıları taşıyanlara ateş etmediğini belirtmektedir. Türklerin düşen İngiliz uçağının pilotlarına dair bir olayı anlattığında yine Türklerin centilmence tavrını vurgulamaktadır: "Türkler genel itibariyle nazik insanlardır. İki havacımız General Nureddin'in kuvvetlerinin eline düstügüunde kampımıza bir Arap görevli ile [pilotların] eşyaları [onlara verilmesi için] gönderildi. Adamlardan sorumlu yetkili biraz para ve bazı eşyalarını teslim etti, ancak mesajı getirip eşyaları götürenler kampa geri ulaştı̆̆ında esirler kuzeye gitmişlerdi, bu nedenle Nureddin eşyaları ve parayı geri gönderdi, bu havacıların misafiri olduğunu ve gönderdikleri eşyalara ihtiyaçları olmadı̆̆ını bildirdi." Düşman olarak Almanlara ne denli öfkeli olduğunu bu muharebeyi anlatırken şu ifadelerle dişa vurmaktaydı: "öğleden sonraya dair tüm izlenimlerimiz boşu boşuna harcanan israf duygularımızı ağırlaştırdı. Almanları çifte halka içerisinde korumada tutan Arapları ve Türkleri değil medeniyetin asıl düşmanı olan Almanları öldürmüşs olmayı umuyorduk"30. 21 Ocak Akşamı çatışmalarını anlattığ 1 9. Bölümün ardından 10. Bölümde kısa süreli ateşkesin nasıl sağlandığını anlatmaktadır. "Să̆ Kiyıya Piyadelerin ilerleyişi”" başlıklı 11. Bölüm 27 Ocakta 1916'da ateşkesin bitip çatışmanın başlamasını anlatarak başlatmaktadır. 8 Şubata kadar 3 çatışmanın 7 Ocak, 13 Ocak ve 21 Ocakta yaşandığını Sol kıyının 7. Bölüğünün nasıl hasar aldığını anlatmaktadır. Kurna'dan Mayıs 1915'te ilk ileri harekattan sonra Kut'taki savaşın önemli bir dönüm noktası olduğunu ve bundan sonra nehir ulaşımının zayıflaması ya da kuvvet yetersizliği nedeniyle Türk kuvvetlerinin takip edilerek yok edilmesini engellediğini belirtmektedir. Bu durumun Türklere yeniden hazırlanması ve organize edilmesi için altı hafta verdiğini ve bu durumun Kut'ta kuşatılmalarının temel nedeni olduğunu belirtiyordu. 10.000 piyade 12 makineli tüfekle Basra'ya ulaştı̆ğı ancak bu kuvvetlerin el Hannah'da çatışmadaki İngiliz birliklerinde nakliye gemisi bulunmadığ 1 için dahil olamadığını belirtmektedir. 12. Bölüm olan Nakliye kısmında harekatta kullanılan nakliye araçlarından, teknik ve pratikte öne çıkan özelliklerinden bahsetmektedir. Bu kısımda ayrıca taşıma için kullanılan nehir araçlarından da söz edilmektedir. Bu anlamda tek hatlı bir demiryolundan daha verimli bir taşıma yapılabildiğini Ezra's Tomb (Ezra Türbesi) ile Qalat Salih (Kalat Salih) ve Amara arasındaki bölgenin gemilerin geçişi için zorlayıcı olduğunu ancak Kurna ile Şattul Arap arasında okyanusa açılabilen gemilerin de kullanılabilecek nitelikte olduğunu belirtmektedir. Bu noktada bazı teknik bilgiler de vermektedir. 400-500 ton taşıyabilen mahaila adı verilen geminin burada kullanılan ana gemi olduğu Misır ve Sudan'da kullanılan nuggar isimli gemiden farklı olarak çok daha fazla yük taşıyabildiğini anlatmaktadır. Bu kısımda diğer başka ulaşım araçlarından da bahsedilmektedir. Bunlardan birisi de aerial adında yarı su üzerinde yüzebilen aynı zamanda havada yol alabilen 50 beygir gücünde yarı dizel motorlu ve "küçük bir çarpışmadan daha fazla gürültü çıkaran" bir araç olarak tespit edilmektedir. Dicle'de geleneksel biçimde taşımacılık yapan taşıtlardan da söz edilmektedir. gufar adı verilen taşıtı "muhtemelen dünyanın en eski gemisi" şeklinde betimlemekte ve çok eskiden beri tüccarların

${ }^{30}$ Candler, Long Road to Baghdad, Vol. I, s. 108-109. 
kullandığına değinmektedir. Ayrıca Mezopotamya'da develerin burun halkaları olmadığı, katırların develerden daha iştahlı hayvanlar olduğu gibi detaylara yer verilmektedir ${ }^{31}$. Candler'in hatıratının 13. Bölümü Sabis Muharebesi ile ilgilidir. 8 Mart 1916 tarihli bu muharebenin öncesi mevzi alışını anlatmaktadır. Bu günlerde Kraldan iki mesaj aldıklarını bunda birliklere duyduğu güveni ve umudu bildirdiğini yazmaktadır. General Keary, General Lake, General Kemball, General Aylmer, General Christian'in hareket tarzları hakkında pek çok detay vermektedir. Çatışmaları çıplak gözle izlediği anlaşılmaktadır: "saldırının üzerinden dört buçuk saat geçmemişti, atla 4 mil kadar General Keary'nin birliğinin tabyanın doğusuna nasıl yayıldığını görmeye gittim. Trajik kayıplara rağmen heyecanlı bir gündü, bu katıksız katliam içerisinde arkadaşlardan birinin kaybını anlamaya zaman yoktu." Çok uzun bir gün olarak ifade ettiği çarpışma için hazırlanan A, B, C birliklerinin hareket tarzlarını anlatmakta kuşatmayı kırma girişiminin neticesindeki zayiatlara dair detayları vermektedir. Girişimin tekrarlanması için ihtiyaç duyulan cesareti askerlerin kaybettiğini belirtmektedir ${ }^{32}$. El Orah başlığını taşıyan 14. Bölümün ardından 15. Bölüm Yarıp Geçmek başlığını taşımaktadır. Bu kısımda askeri harekatın ilerleyişine dair anlatımın yanında İngiltere'den asker yakınlarından gelen mektuplardan bahsetmektedir. Eşini, oğlunu askere gönderen kadınların Candler'e yazdıkları mektuplarda onlardan haber alamadıklarından söz ederek resmini, ismiyle birlikte diğer ayrıntıları yazarak yardım istedikleri anlaşılmaktadır ${ }^{33}$.

Hatıratın 16. bölümü Beytül İsa'da başlığını taşımaktadır. 8 Mart saldırısında başarısız

HISTORY STUDIES

263

Volume 12

Issue 1

February

2020 olunmasının Townshend'ın garnizonunda tam anlamıyla bir ümitsizlik yarattığı, sel sularının yarattığı etkiyle artık zeminin çamur deryası olarak yürümenin zorlaştığına değinmektedir. Her ne kadar moral kaybı yoksa da yüksek rütbeli subayların kendilerine güveninin olmadığına değiniliyordu. Candler, ünlü kimi generallerin Mezopotamya mezarı oldu demekteydi: "Nixon, Aylmer, Gorringe melankolik biçimde nehirde kayboldu". Candler, can kayıplarını sorgulamakta ve Büyük savaşta insan kaybının beklenen bir şey olduğunu ancak Mezopotamya'da beklenenden daha fazlası ile karşılaştıklarını belirtmektedir. Bu kısımda siper savaşına dair önemli tespitler göze çarpmaktadır. Siperin zorlayıcı koşullarına rağmen Fransa'da askerlerin siperde olmaktan memnun olduğuna değinmektedir ${ }^{34}$.

Candler'in hatıratının Sannaiyat'a (Felahiye) üçüncü saldırı ile ilgili kısmı 17. Bölümü oluşturmaktadır. Candler 22 Nisan 1916'da gerçekleşen üçüncü saldırıyı görmediğini bu sırada 8. Bölük ile birlikte Tower of Babel'de olduğunu belirtmektedir. Candler bundan sonra da Kut'un düşüşünden söz etmektedir. 22 Nisan'da çatışmaları görmek için çaba sarf ettiğini ancak başarılı olamadığını anlatmaktadır. Kut'un alınamamasında bu son çabaları başarısız kılan olayların başında sel baskınının geldiğini yazmaktadır. Eğer sel olmasaydı düşman savunmasının kırılıp kırılamayacağının şüpheli olmasına rağmen yine de Türklere önemli avantaj sağladığının kesin olduğunu belirtmektedir. Sannaiyat'daki çarpışmalarda Türk siperlerine yaptıkları saldırı esnasında Türklerin karşı atağa geçtiğini her iki tarafın da ağır kayıplar verdiğini anlatmaktadır. Sabah 6.58 'de başlayan makinalı tüfek ateşiyle çatışmaların oldukça yıpratıcı ilerlediği Sannaiyat'da Türk tarafının saat 10.00'a ellerinde Kızılhaç bayrakları ile ilerlemesi nedeniyle resmi olmayan bir ateşkes imzalandığını bu sırada Türk hattında bulunan İngiliz askerlerin getirildiğini anlatmaktadır. Burada Alman askerlerin davranışlarındaki "barbarlık" buna karşılık Türklerin insanca davranışları mukayese edilmektedir. Buna dair şu ifadeler dikkat çekicidir: "Bir Alman subay Türklere yaralı Ingiliz askerlerini öldürmek için vurmalarını söylemeye gitti..." Ateşkes sırasında pek çok yaralının

\footnotetext{
${ }^{31}$ Candler, Long Road to Baghdad, Vol. I, s.130-137.

${ }^{32}$ Candler, Long Road to Baghdad, Vol. I, s. 146-151.

${ }^{33}$ Candler, Long Road to Baghdad, Vol. I, s. 175-176.

${ }^{34}$ Candler, Long Road to Baghdad, Vol. I, s. 155-167.
}

\section{History Studies}


toplandığını belirtmektedir. Sannaiyat'ta yaşanan çarpışmalarla ilgili iki karşıt görüş olduğu belirtilmektedir. Kut'un kaderinin Sannaiyat'ta yaşanan savaşa bağlı olduğu öyle ki Townshend'ın garnizonun başarısızlık durumunda mutlaka düşeceği ancak başarılı olunması durumunda mutlaka kurtarılmış olmayacağı şeklinde belirtilmektedir. Sannaiyat'ın ardından Kut'un İngiliz kumandanların korkulu rüyası haline geldiğini, en iyilerin canına mal olan bir yer olduğunu kaydetmektedir. 25 Nisan'da daha fazla saldırı yapmayacakları yönünde emir aldıklarını, kadere ve bu karara boyun eğdiklerini, 28 Nisan'da Kut'un düştüğünü 22.000 kişinin garnizonu kurtarmak uğrunda hayatını kaybettiğini söyleyerek, bu bölümü tamamlamaktadir ${ }^{35}$.

Candler, hatıratın birinci cildinin 18. bölümünde Kut'un teslimini anlatmaktadır. Son mesaj1 General Townshend'dan 29 Nisan'da aldıklarını belirtmektedir. Mesaj şu şekildedir: "Silahlarımı, cephanemin büyük kısmını Halil'e teslime hazır olduğumu söylemek için görevlileri gönderdim...Daha fazla dayanamam. Burada biraz gıdaya sahip olmalyyım. Halil'e bugün söyledim ve Julnar'dan (İngiliz gemisi) yiyecek getirmesi için bir grubu gönderdim." Bir sonraki mesajda bir Türk birliğinin Kut'ta kumandayı ele geçirdiğini bildirmektedir. Kasaba ve askeri kampın bayrak direğine beyaz bayrak çekilmiştir. Kısa zaman sonra da tüm iletişim hattının tahrip edileceği belirtilmektedir. İletişim kabloları, silahlar, tüfekler, hava araçları, cephane, dürbünlerin düşmanın işine yarayabileceği düşüncesiyle yok edildiği anlaşılmaktadır. Türklere gramofon ve plaklarının, sivil kullanım için olabilecek şeyleri bıraktıklarını yazmaktadır. Candler hatıratında 6.000 Hintli, 3.000 İngiliz ve diğer bazı görevlinin Kut’ta teslim olduğunu, tartışmaların devam etmesine rağmen sorumluluğun askerlerin değil politikacıların olduğunu, bu rakamın İngiliz ordusunun tarihinde eşi olmayan bir teslimiyet olduğunu belirtmektedir. En yakın rakamın [Charles] Cornwallis' in 7.073 kişi ile Amerikan iç savaşı sırasındaki teslimiyeti olduğu hatırlatılmaktadır. Dahası Mezopotamya'da iki katından fazla sayıda askerin kuşatmadaki birlikleri kurtarmak isterken yok edildiğini hatırlatmaktadır. Ayrıca yenilmez olarak görülen İngiliz ordusunun prestijini alt üst ederek tıpkı diğer ordular gibi yenilebilir olarak gösterdiğini aktarmaktadır. Kut'un düşüşü ile mecidiye ve Tük kağıt parasının çarşı-pazarda eski değerini yeniden yakaladığını anlatmaktadır. Candler her şeye rağmen General Townshend'a olan saygının eksilmediğini, açlığın yarattığı etki dışında bir şeyi etkilemediğini belirtmektedir. Dahası Townshend'ın kişiliği ile Türkleri etkilediği kılıcının kendisine geri verildiğini İstanbul'da Boğaz'da zafer kazanmış gibi konuk edildiğini, bulunduğu konağın sahibi gibi davranabildiğini yazmaktadır. Halil Paşa'nın Towndhend hakkında şu sözleri söylediğini aktarmaktadır: "Biz O'na (Townshend) Rusların Osman Paşa 'ya yaptı̆̆ gibi iyi zaman geçirteceğiz." Kut'ta teslimiyetten sonra esir değişimi yaşandığı anlaşılmaktadır. Sikhim isimli hastane geminin hasta ve yaralı İngiliz askerleri ile Türk esirlerinin değişimine gidildiğini, teslimiyet sırasında Türklerin İngiliz askerlerine çok iyi davrandığını anlatmaktadır. Bu detaylar içerisinde "Kut garnizonu teslim olduğu zaman düşman tarafindan çok iyi muamele görmüştür. Türk subayların her bir Ingiliz askerine bir avuç sigara verdiği, İngiliz ve Osmanlı erlerin dostça ilişki kurdukları gözlenmişti” ifadeleri dikkat çekmektedir. Bağdat'taki sağlık ve medikal destek sisteminin "oldukça yetersiz ve sefil vaziyette olduğu" tespitinin paylaşıldığına değinilmektedir. Bunları anlattıktan sonra Candler yeniden kuşatma günlerini anlattığ 1 görülmektedir. Garnizonun ilk ayında askerlerin yaşamak için çarpıştığını ve tek korkularının yardımcı birlikler ulaşmadan önce cephanelerinin tükenmesi olduğunu Ocak 1916'da Ali Garbi'den kurtarma birliklerinin hareket ettiği dönemde Kut'taki birliklerin tam kumanya aldıklarını ve bu konuda telaşa neden olacak bir durum olmadığını belirtmektedir. Ali Garbi'den Ocak'ta birlikler harekete geçtiğinde Townshend'ın iaşesinin yetersiz olduğunun düşünülmediğini Aylmer'in birliklerinin tam bir organizasyondan

${ }^{35}$ Candler, Long Road to Baghdad, Vol. I, s. 199-210. 
mahrum olduğunu her bir saatlik gecikmenin hayati olduğu ve dirençlerinin nehir yoluyla buraya ulaşmaya çalışırken boşa harcandığını düşünmektedir. Diğer taraftan Kut'taki duruma dair değerlendirmelerinde sivil halk ile kurulan iletişimden de söz edilmektedir. Kut'a Townshend'ın ve İngiliz askerlerinin girmesinden sonra sivil halka burada kalmak ya da 24 saat içerisinde ayrılmak şeklinde iki seçenek sunulduğu, halkın kalmayı seçtiği belirtilmektedir. $\mathrm{Ne}$ onlar ne de kendilerinin gelecek karanlık günleri tahayyül edemediklerini belirtmektedir. İlk günler çok azının kasabadan ayrıldığını kasabadaki Arap yerleşimcilerin ellerindeki tahıl stoklarının satın alınması ile Kut’taki direnişin 3 ay sürdüğünü aktarmaktadır. 8 Aralıkta Townshend Kut'a ulaştı̆̆ında 4 piyade birliğinin toplam 15.000 piyade, 1000 deve süvar, 400 süvari, 31 hafif silah, yedi ağır silahlı ve birkaç bin Arap kabile birliğini kapsayan askerin karşısında olduğu belirlenmiştir. 9 Aralıkta General Nureddin'in bir mektup göndererek garnizonun teslimini istediği belirtmektedir. Bu kısımda yaşanan çatışmaların neredeyse bir özeti yapılmış görünmektedir. Townshend'ın teslime dair sözlerinden alıntılar yapılmış ve sürecin detayları burada yeniden aktarılmıştır. Bilgiler çok detaylıdır. Türklerin Kafkaslardan gelen 52. Tümen ile takviye edilmesinin yarattığı etki ve Townshend'ın birliklerinin yaşadığı yiyecek sıkıntısı detaylı biçimde ele alınmaktadır. Çalışmanın 19. bölümü Shamal için Bekleme başlığını taşımaktadır. Bilindiği üzere shamal, Basra bölgesinde görülen bir kuzeyli rüzgardır ve yılın belli zamanlarında görülmektedir. Candler bu kısımda Basra bölgesinin arazi ve bitki yapısı anlatarak başlanmakta ve bölgede görülen iklimsel zorlukların yarattığı etkiden de söz etmektedir: "Havadaki yüksek neme rağmen isı 110, 112 fahrenheit dereceye, Temmuz 1917'de 122 fahrenheit dereceye yükseldi ${ }^{\prime \prime 36}$. Candler çekirge yemenin burada yaygın olmasına dikkat çekiyordu. Burada gördüğü insan tipleri ile ilgili de pek çok detay vermektedir. Halkın giyiminde kullandığı aksesuarlardan söz etmekte iklimin kendileri üzerindeki etkisini ortaya koymaktadır: "Mayıs ve Haziranda ve Temmuzun ilk yarlsında farklı tür islların ve vücudun uzun süre zorlanmasina neden olan işkence -özellikle Kuvvet D-Firat ve Şattu'l Arab'ın nemli ve tropik yapısı, Dicle ve Karun'un kavrulmuş yanmış havası, Bushire'nin ağır yüklü havasını tecrübe ettim. Bunlara bağll her çeşit böcek onların hastalıklarl-dizanteri, ateş, cilt hastalıklarl, sarılık... Karun'da çoğunlukla-dog-rot: Köpek çürüğ̈̈-denen hastalıkla ki bu uçan zehirli haşerelerle taşınır, karşılaşabilirsin. Dicle'nin suyu koliktir. Bağdat çıbanı ve Halep hastalığ (Aleppo date) ülkenin diğer hastalıklarıdır. Mezopotamya yanı̆̆g, üzerinde hayatın boyunca taşıyacağın iz bırakır" ${ }^{37}$. Coğrafyanın zorlayıcı etkisi Candler çalışmasında oldukça fazla yer bulmuştur. İçinde bulundukları durum oldukça dramatik görünmektedir. Bu ifadeler içerisinde özellikle hava koşulları ve yüksek sıcaklıkların etkisi dikkat çekmektedir. Karun bölgesinin Asya'nın en sıcak değerlerine sahip olduğunu 44. Merwaras birliğinden bazı askerlerin birkaç saat susuz biçimde güneş altında yürüdükten sonra hayatını kaybettiğini belirtir. Isının siperlerde hesaplanamayacak boyutlara ulaştı̆̆ını yazmaktadır. Kanatlıların yarattığı rahatsızlık ve hastalıkları da uzun uzun betimleyen Candler kum sineği, sivrisineklerin yarattı̆̆1 etkiyi dile getirirken şaşkındır: "gece kanatlılar kaybolur ve sivrisinek ve kum sinekleri onların yerini alır.. bir çok yerde birlikte görülürler ancak bazı yerler vardır ki tanrı tarafindan bizi hasta etmesi için görevlendirilmiş, baş belasıdır”. Isı ile kanatlıların verdiği sıkıntı arasında ilginç bir etkileşim olduğunu görmüşlerdi. Sıcaklığın artması ile kanatlıların azalması belli bir dereceden sonra kanatlıların sıcaktan etkilendiği şeklinde gözlemlemekteydi ve çadırlarda 180 dereceye $^{38}$ ulaşan sıcaklığın onları engellediğini fark etmişlerdi ${ }^{39}$.

\footnotetext{
${ }^{36} 110$ fahrenheit $=43.3$ santigrat derece, 112 fahrenheit=44.4 santigrat derece, 122 fahrenheit $=50$ santigrat derece

${ }^{37}$ Candler, Long Road to Baghdad, Vol. I, s. 230-234.

${ }^{38}$ Metinde belirtilmemişse de fahrenheit cinsinden olmalıdır. Kaldı ki bu da 82.2 santigrat dereceye karşılık gelir ki oldukça yüksek bir değerdir.

${ }^{39}$ Candler, Long Road to Baghdad, Vol. I, s. 234-237.
} 
Hatıratın 20. Bölümü Karun Nehri ve Petrol kuyuları başlı̆̆ını taşımaktadır. Bu bölümde Candler petrol bölgelerini detaylı biçimde anlatmaktadır. Özellikle Ahvaz'daki petrol kuyularını anlattığı kısım I. Dünya Savaşında İngiltere'nin petrolü kontrol etme arzusunu gösteren önemli bilgiler sunmaktadır. Buradaki kabilelerin yapılarını ve savaş karşısında tutumlarını uzun biçimde anlatmaktadır. Bahtiyarileri yani İranlı dağlı kabileleri Almanların etki altına alma çabasını ve bu bağlamda Almanların burada Bahtiyarilere etki etmek için altın verdiklerinden söz etmektedir. Özellikle Bahtiyarilerin Türkler ve Almanlarla işbirliği yaptığını zira onların Rusya karşıtı olduklarını belirtmektedir. Bir kısmının ise İngiliz destekçisi zira Türk karşıtı olduklarını belirtmektedir ${ }^{40}$. Bu kısım Anglo-Persion (İngiliz-İran) Petrol Şirketi'nin tarihi açısından da önemli bilgileri barındırmaktadır. Hatıratın 21. Bölümü The Hun in Persia (İran'da Almanlar) başlığını taşımaktadır. Bu kısımda Türk ve Almanların oluşturduğu Panislamik propagandanın etkisi ve bölge aşiretleri ile ilişkilerden söz edilmektedir. Daha savaşın başlarından itibaren Almanların Bahreyn'den itibaren propaganda elemanları ile etkin olduklarını anlatmaktadır. Bahreyn'e İngiliz birlikleri çıktıktan sonra "Fars, Hayat, Tazianah, Intiqam (Intikam)" isimli Şiraz'da, Kirmanşah'ta Nizam Sultan'ın beyannameleri, "Sedai İslam (Sadayı İslam)" isimli gazetenin ise Bağdat'ta basılıp tüm İran'da dolaştı̆̆ını belirtmektedir. Alman casusları Wassmuss ${ }^{41}$ ve Listermann'ın ${ }^{42}$ kuşkusuz bu propagandada etkili olduğunu vurgulamaktadır. Bu iki Alman casusunun faaliyetlerinden uzunca bahsedilmektedir. Özellikle Alman propagandasının ülkede okullarda şarkı yapılacak şekilde yarattığı etkiden söz eden Candler bir okul şarkısının sözlerini de paylaşmaktadır. Bu şarkının sözlerinin en son dizesi dikkat çekicidir: "Iran, Iran olarak kalabildi, Íslam ve Müslümanların meskenleri [ayakta kalabildi] "43. Candler'in hatıratının bu kısmı özellikle I. Dünya Savaşı propagandasına dair oldukça detaylı ve betimleyici örnekler sunmaktadır. Hatıratın 22. bölümü Eden Bahçesi adını taşımaktadır. Kutsal metinlerde geçen Ezra Bahçesi ile ilgili Candler'in yorumları oldukça karamsar görünmektedir. Bu kısmın ilk cümleleri dikkat çekicidir: "dünyanın en eski ülkesi ancak denizden 350 mil içerisinde ya çok az ya da hiçbir eski şey bulamazsın... Dicle'ye kadar Tizpon'un Kemeri ayakta kalan tek yaputtır. Ezra'nın Mezarı Ezra'nın gerçek mezarı değildir, Eden Bahçesi efsanelerin eğer gerçeklik payı varsa tanınmayacak kadar değişmiştir." Bu kısımda Candler Mezopotamya harekatının daha erken evrelerine dönmektedir ${ }^{44}$. Hatıratın 23. bölümü Nasıriye başlığını taşımaktadır. Nasıriye’ye özel bir kısım açmasının nedenini buranın stratejik önemi olduğu anlaşılmaktadır: "Nasıriye stratejik bir noktadır, Firat üzerinde Basra'yı komuta eder, Irak içinden Merkezi Asya'ya açılan bir kapıdır, silahların ve cephanelerin içerilere naklinin kontrolünü sağlar; inatçı kabilelere karşl yapılacak harekâtlarda bir üstür ve Şattül Hay'a yakındır buradan Dicle'den bir ani saldırlya uygundur",45. Burada Osmanlı Devleti'nin uyguladı̆̆ değerlendirme yapmaktadır: “Mezopotamya'da Türkiye'nin hatası ülkeyi Osmanlılaştırma girişimidir. Bu İttihat ve Terakki Partisi tarafindan uygulanan kasitll bir politikaydl. Türkçe halk arasında resmi dili Muhammed'in dili olan Arapça olan halk arasinda resmi dil ilan edildi. Biz Ingilizceyi Basra Körfezi'nde zorlamış olsak aynı şekilde anlaşılır ve bu politika dini meselelerle de ilgiliydi. Şiiler Şii kanunlarını değil Sünni kanunlarını kabul etmeye zorlandı. Bu

\footnotetext{
${ }^{40}$ Candler, Long Road to Baghdad, Vol. I, s. 247-248.

${ }^{41}$ Alman Lawrence olarak da bilinen Wilhelm Wasmuss [1880-1931] I. Dünya Savaşı yıllarında İran bölgesinde faaliyet göstermişti.

${ }^{42}$ Bir Doktor olan Listermann Bushire konsolosudur. Alman propaganda faaliyetlerinde aktiftir. Bkz: Peter Hopkirk, On Secret Service East of Constantinople: The Plot to Bring Down the British Empire, John Murray, London 1994, s. 95.

${ }_{43}$ Candler, Long Road to Baghdad, Vol. I, s. 264-265.

${ }^{44}$ Candler, Long Road to Baghdad, Vol. I, s. 266-271.

${ }^{45}$ Candler, Long Road to Baghdad, Vol. I, s. 275.
} 
nedenle mahkemelerden uzaklaştılar..., ${ }^{46}$. Bu kısımda Candler, tanıdığı kimi yerlilerin acımasız bölgesel hastalıklar tarafından nasıl aniden hayatını kaybettiğini de anlatmaktadır ${ }^{47}$. Hatıratın 24. bölümü Sicak Hava başlığını taşımaktadır. 19 Mayıs 1916'da Türklerin es-Sinn'i tahliye etmesinin ardından sağ hattın ele geçirildiğini anlatmaktadır. Rus general Baratoff 5.000 süvari ve 4.000 piyade ile Hanikin üzerine yürüyüşü nedeniyle Türklerin kuvvetleri topladığını belirtmektedir. Baratoff ile Türkler arasındaki çarpışmalardan söz eden Candler, inanılmaz derecede yüksek sıcakların askeri operasyonları yürütmeyi imkansız hale getirdiğini belirtmektedir. Birliklerin çeşitli hastalıklardan mağdur olduğunu anlatan Candler ateş, dizanteri, boils (cilt kabarcığı- bakteriyel), kolera, Jaundice (sarılık), scurvy (iskoprit) ile karşılaştıklarını söylemektedir. Genelde yetersiz tayınat dağıtıldığını, genel itibariyle sebzenin yetersiz olduğunu bu durumun hastalıklara neden olduğunu belirtmektedir. Burada bulunan yerel bir bitkinin tuzlu suyla iyi kaynatılması ile sebze niyetine kullanılabildiğini anlatmaktadır. $\mathrm{Bu}$ yemeği kötümserlerin "Nebuchadnezzar" iyimserlerin ise "ispanak" olarak adlandırdıklarından söz etmektedir. Hint askerlerin yemekleri için temel iki maddenin şeker ve sütün her ikisinin de yetersizliğinin yaygın olduğunu söylemektedir. İngiliz beyaz askerlerin et ve sebze beslenme düzenlerinin karşılanmakta güçlük çekildiği, Hindular için sığır etinin bir tabu olduğunu büyük baş hayvan eti yiyerek ruhlarının ölmesindense bedenlerinin ölmesini tercih ettiklerini aktarmaktadır. Müslüman askerler içinse helal kesim ete ulaşım güçlüğünün beslenmeye dair güçlüklerden olduğunu belirtmektedir. Mayıs ve Haziran 1916 arasında her hafta 2.500 askerin Basra'dan Hindistan'a gönderildiğini ülkedeki hastanelerin hasta askerlerle dolup taştığını anlatmaktadır ${ }^{48}$. Mayıs 1916 itibariyle ileri harekatın zorluklarının iyice hissedildiğini belirten Candler Bağdat'a ilerleme için gerekli motivasyonun olmadığını sıcak, hastalık ve yetersiz iaşe nedeniyle askerlerin büyük bir moralsizlik içerisinde olduğunu anlatarak birinci cildi tamamlamaktadır ${ }^{49}$.

Candler'in hatıratının ikinci cildi birinci cildin bıraktığı yerden 25. Bölümle ilerleyiş başlığıyla başlamaktadır. Ne yöne ilerleyeceklerini bilmeksizin geçen bekleyiş sırasında Bağdat'a mı Kut'a mı olacağı yönünde ki tahminlerde çoğunluğun Kut olarak düşündüğünü yazmaktadır. İleri harekat ile başlayan süreci oldukça detaylı anlatarak 26. bölüme Muhammed Abduh Hasan başlığını verdiği görülmektedir. Aralık 1916'da başlayan ileri harekatın detaylarında I. ciltteki anlatımdan daha ayrıntılı bir anlatım göze çarpmaktadır ${ }^{50}$. 27. bölüm Hai Çıkıntısı ve Dahra Bend başlığını taşımaktadır. Candler bu bölüme 13 Aralık 1916'de başladıkları saldırıları neticesinde Samara'y1 23 Nisan 1917'de ele geçirmelerini anlatarak başlamaktadır. Muhammed Abduh Hasan'ın Türlerin tuttuğu ilk güçlü pozisyon olduğunu ve buranın 10 Şubat 1917'de ellerine geçtiğini anlatmaktadır. Bu kısımda Türklerin Hai’de ve Dahra'da kurdukları güçlü siper sisteminden söz edilmektedir ${ }^{51}$. 28. bölüm Çarpışma başlığını taşımaktadır. Bu kısımda Sannaiyat'a ilerleme sırasında yaşananları Candler detaylı bir anlatımla birliklerin hareketlerini tasvir etmektedir ${ }^{52}$. 29. bölümü oluşturan Sannaiyat' Zorlamak başlığı altında ise Türklerin buradan çekilmesine neden olacak çarpışmaları anlatmakta ve nihayetinde Türklerin Halil Paşa'nın emriyle önemli birlikleri Bağdat'a çektiğini, Bağdat'taki Alman yetkililerin ailelerinin Bağdat'tan gönderildiği ve kendilerinin de bir- iki yıldan sonra ilk defa Bağdat'1 alabilecekleri umudunun yeşerdiğini anlatmaktadır. Sannaiyat'ta çarpışmalarda 1414 İngiliz kaybı olduğunu yazmaktadır. Bundan sonra nehirdeki

\footnotetext{
${ }^{46}$ Candler, Long Road to Baghdad, Vol. I, s. 280.

${ }^{47}$ Candler, Long Road to Baghdad, Vol. I, s. 281-282.

${ }^{48}$ Candler, Long Road to Baghdad, Vol. I, s. 285.

${ }^{49}$ Candler, Long Road to Baghdad, Vol. I, s. 294.

${ }^{50}$ Candler, Long Road to Baghdad, Vol. II, s. 1-28.

${ }^{51}$ Candler, Long Road to Baghdad, Vol. II, s. 29-48.

${ }^{52}$ Candler, Long Road to Baghdad, Vol. II, s. 49-56.
} 
İngiliz ordu vapurları ile kara birliklerinin bağlantısının sağlanabildiğini belirtmektedir ${ }^{53}$. Hatıratın 30. bölümü Kovalamaca başlığını taşımaktadır. Bu kısımda Halil Paşa'nın İngiliz birliklerinin Şumran'da yerleşmesinin kendisinin sol kanadını tehlikeye düşürdüğünü anladıktan sonra Bağdat'a çekilme emrini verdiğini anlatarak başlamaktadır. Halil Paşa birliklerinin bir kısmını Şumran'1 tutmak üzere bıraktığı, buranın 14. Bölük tarafından ele geçirilmesinin tüm harekatın en önemli kısmını oluşturduğunu anlatmaktadır. İleri takip harekatı sırasında Türk askerlerden pek çok kayıp verdirilip, esir alındığını ancak çatışmaların kesilmediğini ve 1000 İngiliz askerinin hayatını kaybettiğini anlatmaktadır. Buna rağmen ileri harekatın devam ettiğini ve Türklerden ele geçen askeri alanlarda gördüklerinden bahsetmektedir. Buna göre Aziziye'ye İngiliz birlikleri yerleştiğinde Kut'a direk yolla 55 mil, Bağdat'a 51 mil uzaklıktaydı. Yolda hiçbir iaşe temin noktasının olmaması yani ordunun beslenmesi ile ilgili sorunun kendi aralarında Q olarak kodlanmıştı. Ancak Q yani iaşe ile ilgili nehir yoluyla yapılan destek sayesinde sorun yaşanmadığını belirtmektedir. Bundan sonra Bağdat zorlanacaktı ${ }^{54}$. 31. bölüm Bağdat'a başlığını taşımaktadır. 6 Mart 1917'de takibin devam ettiği Bağdat'a 7 mil kaldığı gambotlar H.M.Ss. Mantis ve Tarantula'nın içerisinde Bağdat'ı ilk kez yokladığını ve kendisinin de bunlarda bulunduğunu yazan Candler, donanmanın hızlı ilerleme konusunda şüphe duyduğunu belirtmektedir. Çarpışmaların hemen her detayını anlatan Candler, 11. Kolordu süvari, Herts Yeoamanry'nin iki filosu, 10. Lancer birliği ve 32. Süvari birliğinin Bağdat'a girdiğini belirtmektedir. Bağdat demiryolu istasyonuna Black Watch birliğinin ilk ulaşma onuruna sahip olduğunu belirtmektedir: "Hunlar (Almanlar) tarafindan Berlin'den uzanan demiryolunun bir gurur nişanesi olarak dizayn edilen terminalin ele geçirilmesi ruhsal, kültürel ve materyal olarak Doğu'nun fethinin ilerleyeceğinin teminatıydl",55. Hatıratın 32. bölümü Bağdat'ta ilk günler başlığını taşımaktadır. İfadeler Bağdat'ın ne denli önemsendiğini ortaya koymaktadır. "Hiç bir şey bizim Bağdat'a girişimizden daha olağan, sıradan resmiyetten uzak olabilir" Ayrıca mukavemetin kırılmış bir şekilde şehre girdikleri anlaşılmaktadır: "İsimsiz bir yol boyunca ilerledik. Güney kapısı kalıntıları yakınında durduk...Ingiltere şerefine büyük bir kalabalık toplandı. Alkışlayarak tezahürat ettiler, Türkler gibi görünen fesli bir adamla dalga geçtiler”. Candler Amerikan konsolosluğuna gittiğini konsolos dışarıda olmasına rağmen dragoman tarafindan ağırlandığını belirtmektedir. Şehirde Araplar ve Kürtlerin değerli olabilecek kereste ve demir devlet mallarını yağmaladığını çekip götürdügünü söylemektedir. İlk günden itibaren Hint-İngiliz birliklerinin çarşı-pazarda devriye atmaya başladıklarını yazmaktadır. İlk günlerde şehre dair izlenimleri oldukça depresif görünmektedir. Kimi düzenlemeler ve birliklerin işgaline dair detaylardan sonra son satırlarda şu ifadeler yer bulmaktadır: "Tüm kötülemelere ră̆men Bağdat'a dair izlenimim [buranın] üzerinde hüzünlü bir güzellik olduğuydu, ${ }^{, 56}$. Candler'in hatıratının 33. bölümü Bağdat Halkına başlığını taşımaktadır. Bu kısımda Candler, İngiltere'nin Bağdat'1 ele geçirmesinden sonra deklare edilen metni direk aktarmaktadır. Bu kısımda Bağdat halkının işgal ve İngiltere karşısındaki tutumları detaylı biçimde anlatılmaktadır. Bu bölümde Candler Yahudi, Hristiyan, Müslümanlar arasındaki anlayış farklarından söz ederken tartışmalı konulara da değinilmektedir. Özellikle Ermenilerin tehciri ile Deyrizor'a Ermenilerin yerleşmesinden bahsettikten sonra olayları geniş bir bağlamda uzun uzadıya anlatmaktadır. İttihat ve Terakki, Almanların sorumluluğu gibi konularda kulaktan duyma bilgileri aktarmakta birebir gözlemi olmayan konuları kişisel tecrübesiymiş gibi anlatmaktadır $^{57}$. Hatıratın 34. bölümü Bağdat sonrası; Ruslarla buluşma başlığını taşımaktadır.

\footnotetext{
${ }^{53}$ Candler, Long Road to Baghdad, Vol. II, s. 57-64.

${ }^{54}$ Candler, Long Road to Baghdad, Vol. II, s. 65-80.

${ }^{55}$ Candler, Long Road to Baghdad, Vol. II, s. 81-96.

${ }^{56}$ Candler, Long Road to Baghdad, Vol. II, s. 97-113.

${ }^{57}$ Candler, Long Road to Baghdad, Vol. II, s. 114-129.
} 
Bağdat'ın ele geçirilmesinin nihai bir yer olarak görülmediği zira Bağdat'ın saldırıya açık, doğal bir engelden mahrum olduğunu belirtmektedir. Yağmurlu mevsimin başlamasıyla nehrin yükselmesinin ordunun işini zorlaştırmadığını, Hanikin yönünde ilerlemeleri sırasında Türklerin direniş göstermediğini belirtmektedir. Bu sefer 4 colomnus (tabur) askerin etkili biçimde beslenip, cephane ve ekipman desteği alabildiğini yazmaktadır. En belirgin çarpışmanın Dicle üzerinde Şattul Admain'de olduğunu, takviye edilen 18. Türk kolordusunun Samara'yı savunmak için ümitsizce çarpıştıklarını, 13. Türk kolordu birliklerinin de benzer biçimde hızlı saldırılar yaptığı ancak bu operasyonlarla ilgili Fırat ve Diyala'da birlikleri takip etmek zorunda olduklarını belirtiyordu. Fırat birliklerinin Türkleri takip ettiği Felluce'yi 19 Mart'ta ele geçirildiğini ancak Türklerin takip ettiğini yazmaktadır. Bundan sonra da tüm çarpışmaları aktarmaktadır, 14 Martta Bağdat'tan uzun bir yürüyüşten sonra Türkleri Mansuriye'de yakaladıklarını, Ebu Cisra'nın, Delli Abbas isimli yerleşim yerlerinin 18 Martta ele geçirildiğini belirtmektedir. İran üzerine yönelen Rus ordusu ile İngiliz birliklerin Kızıl Rabat'ta 2 Nisan'da gerçekleştiğini tespit etmektedir. Türk ordusuna Hamedan'dan çekilme emrinin zamanında verildiğini iki ordunun ilerlediği sahadaki zorlukları da tasvir eden Candler, Türklerin hastalık ve yetersiz beslenme nedeniyle yüksek zayiat verdiğini belirtmektedir. Yol boyunca ölü katırlar, atlar, develer, sığırların dolu olduğunu ve vücutlarının tifüs nedeniyle oldukça zayıf göründüğünü belirtmektedir. Türklerin İran coğrafyasından çekildiğini Diyala nehrinin doğusuna toplandığını belirtmektedir ${ }^{58}$. Candler'in hatıratının 35. bölümü Şattül Edhaim başlığını taşımaktadır. Türk 13. Ordu kuvvetlerinin savunma düzeni aldığını ve bu ordunun, bölgenin en muktedir komutanı İhsan Paşa (Sabis) kumandasında olduğunu belirtmektedir. Burada yaşanan muharebenin Mezopotamya'daki en kanlı muharebelerden olduğunu anlatmaktadır ${ }^{59}$. 36. bölüm Samarra başlığını taşımaktadır. Şattül Edhaim çarpışmasının savaşın sonunu getirdiğini Samarra'nın ele geçirilmesinin bir iki gün alacağını düşündüğünü belirtmektedir. Bağdat'nn ele geçirilmesinden kısa zaman sonra Türk 18. Kolordusunun önemli bir komutanı olan Kazım Karabekir Paşa tarafından kumanda edildiğini belirtmekte ve kendisine İstanbul'a ilerleyerek bir güçlendirme pozisyonu almasının söylendiği ancak buna razı olmayarak istifasını Şevket Paşa'ya sunduğunun esirlerden öğrenildiğini anlatmaktadır. Nisan ayı içerisinde yaşanan çarpışmalar sırasında Türk 13. Kolordusunun üç kez, 18. Kolordunun beş defa yenilgiye uğratıldığını ve 60 mil geri çekildiğini belirtmektedir. 3000 kişinin esir alındığını 60 silah ele geçirildiğini ve tüm bu başarıların kışlık kıyafetler içesindeki İngiliz birliklerinin inanılmaz yaz sıcağı altındaki çarpışmalarının neticesi olduğunu belirtmektedir. Hatıratın 37. bölümü Çöl'ün Çiçeklenmesi başlığını taşımaktadır. Bu kısma Mezopotamya'nın korkunç yazının yaşandığını belirterek başlamaktadır. Hatta Bağdatlıların da hayatları boyunca yaşadıkları en sıcak yaz olduğunu söylediklerini belirtmektedir. Aşırı sıcaklar nedeniyle herkesin sağlığının kötüye gittiğini ancak Bağdat'ı ele geçirdiklerinden beri burada pek çok olumlu değişikliğin yaşandığını cadde 1şıklarının tamir edildiğini, insanların gündüz işe giderken akşam evlerine döndükleri olağan bir yaşama kavuştuklarını, camilerin tamir edildiğini okulların açıldığını ve öğretmenler için eğitim okulu açıldığını anlatmaktadır. Hayvanların bakıma alındığını ve yeniden yük taşıyabilir hale getirildiğini, çarşı-pazarın kontrol edilerek zahire ihtiyacının temini işinin ele alındığını, fiyatların düzenlendiğini, yerel yönetimin (belediye) işlerlik kazandığını ve Dicle'nin iki yakasını birleştiren iki köprü inşa edildiğini anlatmaktadır. Bağdat'ta karşılaşılan olumsuz durumu betimlerken Türkleri sorumlu tutmakta ve Türklerin belediyecilik, eğitim, hukuk, ekonomi yönetimi gibi çok çeşitli konularda eleştirmektedir ${ }^{60}$. Hatıratın 38. bölümü İncil ve Babil başlı̆̆ını taşımaktadır. Türk ordusunun

\footnotetext{
${ }^{58}$ Candler, Long Road to Baghdad, Vol. II, s. 130-150.

${ }^{59}$ Candler, Long Road to Baghdad, Vol. II, s. 151-164.

${ }^{60}$ Candler, Long Road to Baghdad, Vol. II, s. 180-193.
} 
geri çekilişi sırasında yaşanan ilginç bir hikayeden bahsedilmektedir. Mehmed Efendi isimli 40 yaşlarında bir Türk subayından ve onun karakteristik davranışından söz edilmektedir. Askerlikten gelme bu kişinin üç savaş gördüğü, Divaniye'de alt rütbeli bir subay olarak görev yaptığ sırada burada garnizonun yok olduğunu görünce kumandayı ele aldığ1 üssünü tutuklayarak astığ 1 , diğer ikisini de revolveri ile vurduğu diğer üç kişiyi de yaraladığı bunların kaçarak kurtulduğu belirtilmektedir. Mehmed Efendinin üslerinin teslimiyet kararına karş1 çıkarak giriştiği bu hareketlerden hayli etkilenen Candler, hatıratında olaya dair yerli Araplardan farklı anlatımlar dinlemiş ve hatıratında bu görüşlere yer vermiştir. Bazılarının anlatımından bir Don Juan karakteri gördüğü Mehmed Efendi için bazı Araplar komutayı ele almak için üslerini öldüren bir asker yakıştırması yapmıştı. Bu fikirleri kafasında toparlayan Candler yine de Mehmed Efendi'de bir "Plevne Ruhu” olduğunu düşünmektedir. Bu bölümde General Allenby'nin harekatını hatırlatarak kutsal inançların tarihsel ve 1917'nin dünyasında karşılaştırmalarını yapmaktadır ${ }^{61}$. Bölüm 39, Necef başlığını taşımaktadır. Kerbele, Necef ve Kazımiye gibi kutsal şehirlerin önemini anlatmaktadır. Bu şehirlerin Şii inancın önemli merkezleri olduğunu yazan Candler buralarda gözlemlediği dini ve geleneksel davranış kodlarını anlatmaktadır ${ }^{62}$. 40.Bölümün başılı̆ı Yeni Saldırı: Ramadi şeklindedir. Candler Bağdat'a uzanan yolun hedeflediklerinden hızlı ilerlediğini belirtmektedir. 1917'nin serin hava dönemi başlarken Türklerin Dicle üzerinde Cebel-i Hamrin'de toplanmaya başladıklarını belirtmektedir. Almanların büyük bir ordu ile gelecekleri ve Bağdat'ı tekrar ele geçirecekleri söylentilerini duyduklarını belirtmektedir. Ramadi üzerine İngiliz askerlerinin saldırısını detayları ile anlatan Candler, burada 145 subay olmak üzere 3,545 esir, 13 silah, cephane, ekipman ele geçirildiğini belirtmektedir ${ }^{63}$. Hatıratın 41. Bölümü Cebeli Hamrin ve Tikrit başlığını taşımaktadır. 5 Kasımda Tikrit üzerine İngiliz birliklerinin yüklendiklerini burada Türklerin 7 mil uzunluğunda bir siper sistemi inşa ettiklerini belirtmektedir. Saldırılar sırasında Türklerin iki kez karşı atak yaptıklarını ertesi gün buranın ele geçirildiğini anlatmaktadır ${ }^{64}$. Hatıratın 42. Bölümü General Maude'nin Ölümü başlığını taşımaktadır. 18 Kasım 1917'de General Maude'nin Bağdat'ta koleradan ölmesinin Mezopotamya harekatının en kötü gelişmelerinden birisi olduğunu ve Maude'nin hizmetlerinin önemini açıklamaktadır ${ }^{65}$. Hatıratın 43. bölümü Kara Tepe başlığını taşımaktadır. Diyale yukarısında Mansuriye'de Cebeli Hamrin ve Kara Tepe geçidinde 13.Kolordunun toplanmakta olduğunu belirtmektedir. Burada Rus Partizanski faaliyetlerine değinmektedir. Sakal Tutan geçidi, Kara Tepe bölgesindeki hem iklimsel zorlukları hem de ordunun ilerleyişini anlatmaktadır ${ }^{66}$. Hatıratın 44. bölümü Hit, Han Bağdadi, Kerkük başlığını taşımaktadır. Fırat üzerinde diğer çarpışmanın Ramadi'den sonra Hit'te toplanan Türk birlikleri ile gerçekleştiğini, General Marshall'ın Hit'i ele geçirmeye karar vermesiyle 19 Şubatta Ukba (Uqbah)'a ilerlendiğini ve buranın zabdedilmemiş görüldüğünü anlatmaktadır. Hit'e 9 Martta giren İngilizler, Salahiye'ye 10 Martta girdiklerini Türklerin Han Bağdadi'ye girdiklerini belirtmektedir. Han Bağdadi'de Türklerle cereyan eden çarpışma neticesinde buranın çöktüğü Ana'da Türk-Alman birliklerinin kullandığı silah-cephane deposunun patlatıldığını anlatmaktadır. Bu depoda 50.000 patlayıcı, 50 milyon küçük çaplı silah cephanesinin havaya uçurulduğunu belirtmektedir. 1918 yaz seferi büyük bir hareketlenme ile bitmektedir. Bu dönemde operasyonlar Kifri bölgesindedir. 24 Nisan 1918'de Kifri-Kerkük-Musul yoluna yöneldikleri çarpışmada 150 Türkün hayatını kaybedip, 538'nin esir düştüğünü 2 dağ bataryasının alındığını belirtmektedir. 6 Mayısta Tuz

${ }^{61}$ Candler, Long Road to Baghdad, Vol. II, s. 194-207.

${ }^{62}$ Candler, Long Road to Baghdad, Vol. II, s. 208-220.

${ }^{63}$ Candler, Long Road to Baghdad, Vol. II, s. 221-236.

${ }^{64}$ Candler, Long Road to Baghdad, Vol. II, s. 237-245.

${ }^{65}$ Candler, Long Road to Baghdad, Vol. II, s. 246-251.

${ }^{66}$ Candler, Long Road to Baghdad, Vol. II, s. 252-258. 
Hurmat1, 7 Mayısta Kerkük'e girdiklerini, 11 Mayısta Aşağı Zap'ın Türklerden temizlendiğini belirtmektedir $^{67}$. Hatıratın 45. bölümü Sonuç kısmıdır. Burada Mezopotamya harekâtının genel bir muhasebesi ve değerlendirmesi yapılmaktadır. Candler'in ifadesi ile Mezopotamya harekâtının iki temel amacı vardır: Hindistan'ın güvenliği ve Türklerin yok edilmesi. Candler Türklerin, Almanların bir savaş silahı olarak iki tarafı da keskin bir kılıca sahip olduklarını bunun da Hilafet makamı olduğunu iddia etmektedir. Savaşın son kısmı da olayların hızla Türkler aleyhine ilerlediğini belirtmektedir. 31 Ekim'de ateşkesten bir gün öncesi itibariyle Dicle karşısında tüm Türk kuvvetlerinin sarıldığını belirtmektedir. $\mathrm{Bu}$ kısımda Mezopotamya'nın ele geçirilmesinin İngiliz ordusuna maliyetini de vermektedir: subay 4.335 ölü (1340'1 muharebede, yaralanma ya da hastalıktan ) diğer rütbelerden 93.244 kişi. Hatıratın sonunda Victoria madalyası alan İngiliz ordu mensuplarının bir listesi bulunmaktadır ${ }^{68}$.

Hatıratında savaşın korkunç yüzüne dair bu detayları gördüğümüz Candler'in Hint birliklerine dair anlatımları ile haber içerikleri senkronize ve eşzamanlıdır. Elbette hatırattaki anlatımın olayların tamamının yaşanmasının ardından sonlandırılmış, düzenlenmiş olduğundan daha bütüncül bir bakış açısıyla kaleme alındığı ve ordunun harekât planlarını ve amacını açıkladığı anlaşılmaktadır. Diğer taraftan haberlerde yer verilen bazı konulara dair kitapta çok dikkat çekici fotoğrafların yer aldığı görülmektedir. 16 Şubat 1916 'da çıkan haberde askeri hareketliliği zorlaştıran çamurdan söz eden Candler ${ }^{69}$ hatıratında bunu bir fotoğrafla da desteklemektedir (Ek 2). Candler'in hatıratında harekâtlara dair harita ve çizimlere de rastlanmaktadır. 8 Mart 1916 tarihli saldırıya dair ayrıntılı harita bunlardan ilkidir (Ek 3). I. Ciltte Townshend'ın ve kurmaylarının esir düşmesinden sonra çekilmiş çok net bir fotoğrafa da yer verilmektedir (Ek 4). Daha uzun ve kapsamlı olan ikinci ciltte de birinci ciltteki gibi çok dikkat çekici görseller yer almaktadır (Ek 5).

Haber içerikleri ile hatırattaki bilgiler kıyaslandığında hatıratta olayların çok daha detaylı ve uzun anlatılması dikkat çekmektedir. Örnek üzerinden bakmak için Candler'in Şeyh Said'de yaşanan çarpışmalara dair The Times'e yazdığı haber içerikleri ile hatıratındaki Şeyh Said bahsini kıyaslamak faydalı olacaktır. Hatıratta IV. bölüm olarak ele alınan Şeyh Said başlı̆̆ını taşıyan kısım 13 sayfa devam etmektedir. Dahası General Aylmer'in komutasındaki bu birliklerin kayıplarını haberde 550'den fazla Arap ve Türk askerin esir alındığını bunların 16 'sının subay olduğu bilgisine yer verilmesine rağmen $^{70}$ hatıratta bu bilgilere yer verilmemektedir. Hatta İngiliz kayıplarına dair uzun detaylara hatıratta yer verilmektedir. Buna göre Seaforts birliklerinden 20 subaydan 5'i öldürülmüştü, 15 'i yaralıydı. Toplamları 880 kişiydi ${ }^{71}$. Rakamlar bir tarafa hatıratta Şeyh Said ile ilgili çok duygusal bir anlatım göze çarpmaktadır. Özellikle yaşanan çatışmaların ardından yaşanan sağlık hizmetlerinin yetersizliğini uzunca anlatan Candler'in betimlemeleri yaşananları gözler önüne sermektedir: "Akşam 8'de yăgmur yăğd. 9'u sabahı Türkler pozisyonlartnı tahliye edince daha fazla yaralı bulundu ve taşındl... 100 yatakl bir tıbbi ünite basit bir kalem müdahalesiyle 1000 yatakl genel hastaneye dönüstürüldü̈. Bir Hint birliği uyduruk bir hastanede tüm öğleden sonra yemek pişirdiler, zira yaralılar çok açtılar, hastaneye koştular. Açlık, takatsizlik ve tedaviyi geciktirmek yüzünden pek çok yara septik ve kangren biçimini aldı. Daha az ciddi yaralı olanlar botlara taşındl... yağmurdan koruyan basit bir düzenek ile Amara'ya hastaneye götürüldüler. Bu yolculuk için yeterli doktor ayrllamadığı için bu yaralıların pek çoğu

\footnotetext{
${ }^{67}$ Candler, Long Road to Baghdad, Vol. II, s. 259-277.

${ }^{68}$ Candler, Long Road to Baghdad, Vol. II, s. 278-300.

69 "Turkish Desertions in Mesopotamia. Transport Difficulties in the Mud", The Times, 16 Şubat 1916.

${ }^{70}$ Candler, "A Most Gallant Attack. Whole Turkish Battalion Account For", The Times, 12 Ocak 1916.

${ }^{71}$ Candler, Long Road to Baghdad, Vol. I, s.51-52.
} 
dikkatsizlik nedeniyle öldüler",72. Anlatılar Şeyh Said'dan sonra daha duygusal bir tona evirilmiş görünmektedir: "Şimdi ama ciddi, eğitimli görünen bir İskoç hattın karşısındaydl, gözleri [üzerine örtülmüş] bir The Times sayfasına baklyordu. Bandajı birkaç saat önce savaşmakta olduğunun kanıtı şimdiyse başka iklimlere gitmiş Cobbett ile at sürüyor ya da Walton'un 1583 'lerde Richard Hooker ile evliliğini okuyor ya da George Herbert'i dinliyordu ..., ${ }^{, 73}$.

Candler haberlerinde belli oranda girişilen işin zorluğunu aktarmıştır. Düşman olarak Türklerin hazırlıklarından bahsederken attıkları doğru adımları takdir etmiş̧tir. Candler haber metinlerinde doğanın harekatta zorlayıcı etkisinden sıklıkla bahsetmiştir. Candler Şeyh Said'deki Türk siperleri ile ilgili "mükemmel" ifadesini kullanmakta ve birliklerin hareketini engellemeyen bu siperler yanında coğrafyanın savunmada olan orduya sağladığı üç kolaylıktan söz etmektedir. Bunlardan ilki içerilere ilerledikçe su kaynağının olmayışı, Dicle çevresinde bazen bir iki mil uzanan kaygan çamurlu pek çok sahanın bulunması ve son olarak da zeminin yükseltiye sahip olmayan bir düzlük olması olarak sıralamaktadır ${ }^{74}$. Haberlerinde İngiliz ve Hint askerlerinin itidallerini kaybetmeme noktasında benzer olduklarını anlatan Candler, askerlerin bu davranışlarından övgüyle söz etmektedir. Fransa'dakinden farklı olarak Mezopotamya'da motorlu ambulansların yokluğunu hatırlatarak askerlerin karşılaştıkları güçlüklerin altını çizmektedir ${ }^{75}$.

Kut'ta General Townshend'ın teslimiyetine kadar olan gelişmeleri, girişimleri, yetersizlikleri, iklim, coğrafi zorlukları aktaran Candler'in teslimiyetten sonra The Times'e yazdığı dört haberde teslimiyetin meşru gerekçelerini açıklamıştır. Ayrıca bu haberlerde Türklerin Townshend'a yönelik davranışlarının centilmence olduğunu yazmıştır. Başka haberlerde de zaman zaman yazdıklarının tekrarı niteliğinde Türklerin Almanlar sayesinde bu başarıyı elde ettiklerine yer vermiştir ${ }^{76}$. General Townshend'ın esir alınmasının ardından teslimiyetin kaçınılmaz olduğunu aktaran haberler yazmıştır. Bu haberlerde Kut'taki teslimiyete kadar olan gelişmeler kısaca sıralanmakta ve teslim olma kararının yerinde bir karar olduğunu anlatmaktadır. Candler Türklerin savaş taktiklerini de ortaya koymakta ve zaman zaman eleştirmektedir. Almanların Batı cephesinde uyguladığı bir taktiğin Türkler tarafından uygulandığına değinmektedir. Söz konusu taktik, ateş edilen siperleri hafif güçle tutup, İngilizlerin saldırısına bağlı olarak karşı saldırı ile İngilizlerin merkezini ele geçirmeyi temel almaktadır. Bu taktiğin nedeninin savunmanın saldırıdan daha çok kayıp verdiren-maliyetli bir yöntem olması nedeniyle tercih edilmesi olarak açıklamaktadır ${ }^{77}$.

İngiliz birliklerinin teslim olmasının ardından çıkan haberlerde Candler, Kut'ta yaşanan erzak sıkıntısına dair detayları daha net biçimde aktarmaya başlamıştır. Hasta İngiliz esirlerinin serbest bırakılması ile Captain F.G. McLean, (78. Pencabi birliğinden), Teğmen J.H. Bulloch ve F.W. Postmouth (2. Norfolk birliğinden), W.A.G. Hinds (103. Mahratta birliğinden) ile Candler'in röportaj yaptığı anlaşılmaktadır. Candler bu dört ismin de Kut'taki hastanede 25 Aralıktan Nisan başına kadar kalan hasta askerler olduğunu belirtmektedir. Askerler Candler'e, Kut'taki iaşe yetersizliğinin özellikle hastanede Şubat ortasında başladığını hasta ve yaralılara

\footnotetext{
${ }^{72}$ Candler, Long Road to Baghdad, Vol. I, s. 58

${ }^{73}$ Candler, Long Road to Baghdad, Vol. I, s. 61-62.

${ }_{75}^{74}$ Candler, “Trying Conditions The Tigris. Turks’ Admirable System of Defences”, The Times, 7 Şubat 1916.

75 Candler, "Battle Pictures on the Tigris, The Field of Sheikh Saad. Stoicism of the Wounded", The Times, 23 Şubat 1916.

${ }_{77}^{76}$ Candler, "Last Messages from Kut, Gen. Townshend's Surrender, Turkish Chivalry, The Times, 10 May1s 1916.

77 Candler, "Battle Pictures on the Tigris, The Field of Sheikh Saad. Stoicism of the Wounded", The Times, 17 Ocak 1917.
} 
verilen sütün yerini mısır ya da pirinç suyu aldığını söylemişti. Dahası askerler yük hayvanlarının kesilip yenilmesinden de bahsetmişler ve bu beslenme şeklinden "Kut Food [Kut yiyece ği]" olarak bahsetmişlerdi. Bu detaylar içerisinde katırların at etine tercih edildiğini zira katır etinin daha yağlı olması sayesinde bunun koyun yağına alternatif oluşturduğunu anlatmışlardı. Bunlar savaşın zorlayıcı yönünü göstermesi açısından dikkat çekicidir. Hasta Kut askerleri kuşatma sırasında tütün yetersizliği yaşadıklarını da anlatmışlardı. Gazete askerlerin aktardığı bu bilgileri Tütün Kıtllğgl "[Tobacco Famine]" olarak yansıtmıştır ${ }^{78}$.

Kut'un düşmesinden sonra askeri gelişmelerin İngiltere lehine dönüşmesi İngiliz birliklerinin 1917 Martında Bağdat'ı ele geçirmesiyle neticelenmişti. Candler hatıratında dikkat çekici bir biçimde Bağdat'a girişe dair duygusal tespitlere yer vermekteydi: "dünyanın en efsanevi şehri, kapılarını somutlaştırılmış hassasiyete açmıştı" ". . Kut'un düşüşü ile Bağdat'ın İngiliz birliklerince ele geçirilmesine kadar geçen zaman dilimi içerisinde ileri harekata dair detayların aktarıldığı görülmektedir. Bağdat'ın düştüğü güne dair haberde halkın İngiliz ordusunu içtenlikle karşıladığını zira uzun zamandır ordunun ihtiyaçları nedeniyle halkın "soyulduğu" iddia edilmektedir. Türklere karşı olumsuz bir imaj oluşturan bu ifadelerinin yanında Bağdat'ın İngiliz birliklerince ele geçirilmesinin Hindistan'da huzursuzluğa neden olduğuna yer verilmesi de önemlidir ${ }^{80}$. Candler'in bundan sonraki yazdığı haberlerin hepsi Bağdat ve Mezopotamya'daki İngiliz varlığı ile ilgilidir. Hatıratı da İngiliz-Hint birliklerinin Mayıs 1918'e kadar yürüttükleri harekâtları anlatarak tamamlanmaktadır ${ }^{81}$. Bu anlamda The Times'da çıkan haberler ile hatıratındaki anlatımları senkronizedir. Candler'in hatıratında da gazete haberlerinde de kariyerini inşa ettiği Hindistan ve Hintlilerin savaştaki özverilerini ön planda tutan bir anlatıma sahip olduğu görülmektedir.

\section{Sonuç}

Volume 12

Edmund Candler'in Irak harekâtı gözlemciliği ve onun aktarımı ile The Times'de çıkan haberleri diğer yandan da hatıratını ele alan bu incelemenin birkaç farklı açıdan son bir değerlendirmeye ihtiyacı bulunmaktadır. Birincisi I. Dünya Savaşı ve basın-gazetecilik ve propaganda ilişkisi ile ilgili olmalıdır. Candler'in 1915 sonunda ulaştı̆̆ 1 Mezopotamya'daki İngiliz harekâtına dair gözlemlerini The Times'a aktarımı ve gelişmelerin haber oluş şekline bakıldığında savaşın asker ve ordu görevlisi herkes üzerinde ne denli etkili olduğunu görmek mümkündür. Hatıratındaki daha trajik sahneler her ne kadar haberlerde daha az göz önüne serilmişse de İngiliz okuyucu, katır eti ile beslenen açlıkla mücadele eden askerlerin teslimiyetini olaylara eş zamanlı olarak takip edebilmiştir. Haberlerin aktarımında ciddi manipülasyonlar göze çarpmamaktadır. Ancak haberlerde harekâtın meşruiyetini ve gerekliliğini sorgulayan bir eleştiriye de girişilmediği belirtilmelidir. Zaten hatıratında da Candler harekâtın gerekliliğini savunmakta ve türlü kayıplara rağmen iki açıdan gerekli olduğunu açıklamaktadır. Bunlardan ilkini Hindistan'ın güvenliği olarak belirlemektedir. İkinci amacı ise Türklerin Mezopotamya'dan çıkarılması olarak belirlemekte hayati olan birinci amacın aslında ikinci hedefi de içine aldığına yer vermektedir ${ }^{82}$.

I. Dünya Savaşı sırasında yaşanan en büyük yenilgilerden birisi olarak İngiliz yetkililerin Irak harekâtında (özellikle Kut'ta sıkıştırılmaları ve teslimiyet) yaşananları kamuoyundan tamamıyla gizlemek gibi bir tasarrufları olamayacağı açıktır. Bu durumu çok uzun zamana

\footnotetext{
78 “Five Monts in Kut, Defenders' Own Narrative. Privations of Garrison. Tobacco Famine", The Times, 19 May1s 1916.

${ }^{79}$ Candler, Long Road to Baghdad, Vol. II, s. 97.

${ }^{80}$ Candler, "In Baghdad, Unbounded Relief of Populace. Looting and Robbery Stopped", The Times, 16 Mart 1916.

${ }^{81}$ Candler, Long Road to Baghdad, Vol. II, s. 276-277.

${ }^{82}$ Candler, Long Road to Baghdad, Vol. II, s. 278-279.
} 
yayılan İngiliz kamuoyu farkındalığının gücüne ve yönetilenlerin yani halkın yöneticiler üzerindeki etki faktörüne bağlı olarak düşünmek gereklidir. Bu bağlamda I. Dünya Savaş1 sırasında Osmanlı basınında yer alan haberleri ve bu haberlerdeki detayları göz önüne almak kıyaslamaya imkân sağlamaktadır. İstanbul'da yaşayan bir Osmanlı tebaasının basın yoluyla Bağdat'ın düşüşünden haberdar olması için aylar geçmesi gerekecekti. Olan bitenin haber yapılamadığı bir basın sansüründen söz ederken yaşananlara dair Candler'in sıcak çatışma bölgesinden aktardığı haberlerde açlık, ölüm ve savaşın yıkıcılı̆̆ına dair detayların belirli bir kahramanlık boyutu eklenerek ve gerçekliğine çok yakın biçimde haber olması Mezopotamya harekâtı ile ilgili de önemli bir bilgi külliyatı oluşturmaktadır. Yine de bu haberlerin de mutlak surette tenkit edilerek değerlendirilmesi gereklidir. Bunun için de hatıratı önemli bir kaynaktır. Burada olayları çok daha detaylı ve insan unsurunu, yaşanan zorlukları ön planda tutarak anlatmaktadır. Anlatımları içerisinde savaşın zorlayıcı yönleri yanında bir düşman olarak Türklerin centilmenliğini hatıratında net biçimde ortaya koyan Candler, yazdığ 1 haberlerde böyle bir imada bulunmamaya dikkat etmiştir. Diğer taraftan Almanların savaş yöntemlerini eleştirmiş ve onlardan neredeyse istisnasız zamanın Hunları olarak söz etmiştir.

Candler'in The Times'e yazdığı haberler ile hatıratı Mezopotamya Harekatının gerçekleştiği dönemde cephe gelişmelerinin nasıl haber olduğunu ve savaşın ardından yazdığı hatırat ise savaş gerçeğinin aslında sarsıcı yönünü anlamak adına önemlidir. Bu iki ciltlik hatırat İngiliz birliklerinin harekatını gözlemleyen bir muhabirin kaleminden çıkmış olması, çok detaylı bir anlatıma sahip olması, gibi nedenlerden son derece önemlidir ve Osmanlı Devleti'nin en önemli cephelerinden birini oluşturan Irak-İran cephesini anlamak adına önemli veri sağlamaktadır.

\section{Kaynakça}

“A Most Gallant Attack. Whole Turkish Battalion Accounted For”, The Times, 12 Ocak 1916.

"Five Monts in Kut, Defenders' Own Narrative. Privations of Garrison. Tobacco Famine", The Times, 19 Mayıs 1916.

"Goliath Lost in the Straits, Torpeded by Turks at Night", The Times, 14 May1s 1915.

"In Baghdad, Unbounded Relief of Populace. Looting and Robbery Stopped", The Times, 16 Mart 1916.

"Last Messages from Kut, Gen. Townshend's Surrender, Turkish Chivalry", The Times, 10 Mayıs 1916.

Our Naval Correspondent, "Naval Gains and Losses, The Fate of the Goliath", The Times, 14 May1s 1915.

"Plundering Arab Horsemen", The Times, 21 Şubat 1916.

"The March on Kut",The Times, 12 Ocak 1916.

“Trying Conditions The Tigris. Turks' Admirable System of Defences", The Times, 7 Şubat 1916.

"Turkish Desertions in Mesopotamia. Transport Difficulties in the Mud", The Times, 16 Şubat 1916.

"Von der Goltz to go to Mesopotamia", The Times, 7 Aralık 1915.

BEST, Brian, Reporting from the Front. War Reporters during the Great War, Pen\&Sword, London 2014. 
Birinci Dünya Harbinde Türk Harbi Irak- Iran Cephesi, 3. Cilt, 1. Kısım, Genelkurmay Basım Evi, Ankara 1979.

CANDLER, Edmund, Long Road to Baghdad, Vol. I-II, Cassell and Company Ltd., London, New York, Toronto 1919.

CHOWDHURY, Sharmishtha Roy, The First World War, Anticolonialism and Imperial Authority in British India, Routledge London 2019.

FERGUSON, Niall, Hazin Savaş 1914-1918, (Çev. Nurettin ElHuseyni), YKY Yay., İstanbul 2015.

HOPKIRK, Peter, On Secret Service East of Constantinople: The Plot to Bring Down the British Empire, John Murray, London 1994.

KNIGHTLEY, Philip, First Casualty: The War Correspondent as Hero and Myth-Maker from the Crimea to Iraq, Johns Hopkins University Press 2004.

KÖROĞLU, Erol, Türk Edebiyatı ve Birinci Dünya Savaşı (1914-1918) Propagandadan Milli Kimlik İnşasına, İletişim Yay., İstanbul 2004.

KÖROĞLU, Erol, "Propaganda mı, Kültür Savaşı mı? Birinci Dünya Savaşı Dönemi Türk Edebiyatında Cihat, İslam ve Milliyetçilik", Âb-ı Hayat-l Aramak Gönül Tekin'e Armağan, (Yay. Haz. Ozan Kolbaş, Orçun Üçer), Yeditepe Yay., İstanbul 2018, ss.451468.

LUCKHURST, Tim, "War Correspondents", in: 1914-1918-online. International Encyclopedia of the First World War, ed. by Ute Daniel, Peter Gatrell, Oliver Janz, Heather Jones, Jennifer Keene, Alan Kramer, and Bill Nasson, issued by Freie Universität Berlin, 2016$03-15$

MESSINGER, Gary S., British Propaganda and the State in the First World War. Manchester, Manchester University Press, 1992.

POLAT Ü. Gülsüm, Osmanlı Devleti ve İngiltere Ekseninde I. Dünya Savaşı Yıllarında Mısır, ATAM Yay., Ankara 2015.

POLAT, Ü. Gülsüm, "Başarılı Savunmadan Esarete: İngiliz Basınında Kûtü’l Amâre Kuşatması", 100. Yllında Uluslararası Bağdat (Medînetü's Selâm) ve Kûtü'l Amâre Sempozyumu, İstanbul, 20-22 Aralık 2017.(Basım aşamasında),

POLAT, Ü. Gülsüm, “Esir Kut Komutanı Townshend'ın İstanbul'a Getirilişi ve İngiliz Savaş Basınına Müdahale", Akademik Ortadoğu, C. 9, Sayı: 2, ss. 131-145.

TOWNSHEND, Charles F.V., My Campaign in Mesopotamia, Thornton Butterworth Limited, London, 1920. 
Ek 1: Haber Başlı̆̆ı yanında yer alan tarihler makalede görülen tarihtir. Türkçe çevirinin yanında görülen tarih ise The Times'de yayınlandığı tarihtir. Haberler Edmund Candler'in bildirdikleridir.

1. Haber Başlı̆̆ “A Most Gallant Attack. Whole Turkish Battalion Account For” [En Cesur Taarruz. Bütün Türk Birliği Hesaplandı] 12 Ocak 1916

2. Haber Başlığı: "Germans Directing the Attack", Expeditionary Force in Mesopotamia", Basra, 11 Jan.

[Saldırıyı Almanlar Yönetiyor, Mezopotamya Seferi Kuvvetleri], Basra, 17 Ocak 1916

3. Haber Başlığı: “General Aylmer's Advance, Fine Feats by the Infantry, Conspicuous Gallantry of the Troops", Basra, 16 Ocak

[General Aylmer'in İlerleyişi. Piyadelerin iyi özellikleri. Birliklerin Dikkat Çekici Kahramanlığ1], 22 Ocak 1916

4. Haber Başlı̆̆1: "From France to the Tigris. Highlanders of East and West. Diversions in a Transport”. Persian Gulf, off Fao, 30 Aralık

[Fransa'dan Dicle’ye. Doğu ve Batı Yaylaları] 29 Ocak 1916, İran Körfezi, Fao, 30 Aralik

5. Haber Başlığı: "Turks Flooded out at Kut. All Well in British Camp. Weather Improving", Army Headquarters, via Basra, 28 Jan.

[Türkler Kut'ta Sel Baskınına Uğradı. İngiliz Kampında Herkes İyi (Durumda), Ordu Karargâhı, Basra Aracılığıyla, 28 Ocak], 3 Şubat 1916

6. Haber Başlı̆̆ı: "Turkish Desertions in Mesopotamia. Transport Difficulties in the Mud", Expeditionary Force, Basra, 11 Feb.

[Mezopotamya' da Türkler Firariler. Çamurda Nakliyenin Zorlukları], Seferi Kuvvetler, 11 Şubat. 16 Şubat 1916

7. Haber Başlı̆̆ Wily Foes"

[Yağmalanmış Arap Atlısı. Ovalı İsmaililer. Sahte Dostlar. Sahtekâr Düşmanlar] 21 Şubat 1916

8. Haber Başlı̆̆ı: "Trying Conditions The Tigris. Turks' Admirable System of Defences", Basra, Feb.2.

[Dicle'de Gelişen Durum. Türklerin Takdire Şayan Savunma Sistemi], 7 Şubat 1916.

9. Haber Başlığı: "Battle Pictures on the Tigris, The Field of Sheikh Saad. Stoicism of the Wounded", Sheikh Saad, Jan. 13.

[Dicle’de Muharebe/Savaş Manzaraları. Şeyh Said Arazisi, Yaralıların Metaneti], 23 Şubat 1916

10. Haber Başlı̆̆ı: "General Townshend's Invincibles, Sowing Vegetable Seeds at Kut" Supplies by Aeroplane, Basra, Feb., 21.

[General Townshend'in Yenilmezleri. Kut'ta Sebze Tohumu Ekimi. Uçaklarla İaşe Temini], 26 Şubat 1916

11. Haber Başlığ1: "Turks Attacked on the Tigris, The Enemy Completely Surprised", Basra, 23 Feb.

[Dicle'de Türklere saldırı. Düşman Tamamen Şaşkın],13 Mart 1916

12. Haber Başlığı: "A Frontal Attack Near Kut. Contrast with France. Heavy Cost of Fighting in Open Country", Mesopotamia.

[Kut Yakınında Cephe Taarruzu. Fransa ile Zitlık. Açık Bir Sahada Savaşın Ağır Maliyeti,], 13 Mart 1916.

13. Haber Başlı̆̆ı: "Odd Craft on the Tigris. A Medley of Transport Auxiliaries", Mesopotamia 
[Dicle'de Tuhaf Gemi. Yardımcı Kuvvetlerin Naklinde Çeşitlilik], 14 Mart 1916

14. Haber Başlığı: “Tigris Army’s Trusty Servants, The Camel, The Mule, And the Drabi”, Mesopotamia

[Dicle Ordusunun Güvenilir Hizmetkârları. Deve, Katır ve Destekçiler], 15 Mart 1916

15. Haber Başlığı: "Still 23 Miles from Kut,No Ground Gained. 104th Day of the Siege", Orah (On the Tigris), March 16.

[Halen Kut'tan 23 mil -ötede- Yeni Yer Elde Edilmedi. Kuşatmada 104. Gün], 21 Mart 1916

16. Haber Başlığı: "The Attack on Es Sinn, General Townshend's Cooperation, Mesopotamia"

[Es-Sinn'e Saldırı. General Townshend'in İşbirliği], 22 Mart 1916.

17. Haber Başlığı: "A Truce in The Desert, Turks' Arab Allies. Human Vultures of War", Mesopotamia

[Çöl'de Bir Mütareke. Türklerin Arap Müttefikleri. Savaşın İnsan Akbabaları], 22 Mart 1916

18. Haber Başlığı: "New Hospital Ship at Basra. The Floded Tigris", Basra March 26.

[Basra' da Yeni Bir Hastane Gemisi. Dalgalı Dicle], 29 Mart 1916

19. Haber Başlığı: "The Dogra in Battle. A Warrior race from Kashmir" [Savaşta Dogra Irkı. Kaşmir'den Savaşçı Bir Irk], 30 Mart 1916

20. Haber Başlığı: "A Move Towards Kut. Turkish Position Carried. Operations Proceeding Satisfactorily".

[Kut'a Doğru bir İlerleme. Türk Mezvii Taşındı. Operasyon Memnuniyet Verici Biçimde İlerliyor], 6 Nisan 1916

21. Haber Başlı̆̆ı: "Capture of el Hannah. An Operation Thorougly Prepared, Felahieh", April 5.

[el Hannah'ın Ele Geçirilmesi. Bir Operasyon Hazırlanıyor], 11 Nisan 1916

22. Haber Başlığı: "Obstacles on the Tigris. A Waterspout, Floods, And Storms. 134th Day of Siege of Kut". At the front, Falahieh, April 13.

[Dicle'deki Engeller. Hortum, Sel Baskınları ve Firtınalar. Kut'un 134. Kuşatma Günü], Cephede-13 Nisan., 20 Nisan 1916

23. Haber Başlığı: "General Keary's Advance on the Tigris, Troops Attack Waist-Deep in Water". Abu Roman, April 17.

[General Keary'nin Dicle'de İlerlemesi, Birlikler Suya Yarısı batmış şekilde saldırdı], Abu Roman 17 Nisan, 24 Nisan 1916

24. Haber Başlığı: "Turkish Slaughter at Beit Eissa, Six Mass Attacks", Abu Romen, April 18.

[Beytül İsa'da Türk Kıyımı (Kayıbı), 6 Büyük Saldırı], 26 Nisan 1916.

25. Haber Başlığı: "Turks' Heavy Losses in Recent Attacks, Fighting the Tigris", Falahieh, April 25.

[Son Saldırıda Türklerin Ağır Kayıpları, Dicle'de Çatışma], 29 Nisan 1916

26. Haber Başlığı: "Last Messages from Kut, Gen. Townshend's Surrender, Turkish Chivalry", Mesopotamia, May 3.

[Kut'tan Son Mesaj. General Townshend'ın Teslimiyeti. Türk Centilmenliği], 10 May1s 1916

27. Haber Başlı̆ğ: "The Story of Kut, A Fight with Hunger, General Townshend's Great Defence", Kurna, May, 3.

[Kut'un Hikayesi, Açlıkla Savaş, General Townshend'ın Büyük Direnişi], 15 Mayıs 1916

28. Haber Başlığı: "Five Monts in Kut, Defenders' Own Narrative. Privations of Garrison"

\section{History Studies}


[Kut'ta Beş Ay, Müdafilerin Kendi Anlattıkları, Garnizonun Sıkıntıları], 19 Mayıs 1916

29. Haber Başlığı: "Hopping the Parapet, Dash of the New Men at Falahieh", At the Front, Mesopotamia.

[Siperi Atlamak, Falahiye'de Yeni Adamların Çizgisi. Felahiye, Cephe, Mezopotamya], 31 Mayss 1916

30. Haber Başlı̆̆ı: "The Russian Ride to the Tigris. Daring Advance Through the Mountains", At The Front, Mesopotamia, June 5,

[Dicle'ye Rus Taarruzu. Dağlara Cesaretli İlerleyiş], 12 Haziran 1916

31. Haber Başlığı: "The March on Kut, Surprise that Failed, An unfinished Tale, At the Front Mesopotamia", June 5,

[Kut'a İlerleme, Başarısız Olan Sürpriz, Bitmemiş bir Hikâye], 15 Temmuz 1916

32. Haber Başlı̆̆ı: "Kultur in Persia, Brigandage and Murder as a System, German "Organizastion" in Excelsis"

[İran'da Kültür, Bir Sistem Olarak Haydutluk ve Cinayet, En Yüksek Alman Organizasyonu], 17 Ağustos 1916

33. Haber Başlığı: "The Fallen Eden. Terrible Climate of Mesopotamia. Some Biblical Landmarks", Kurna

[Eden'in Düşüşü. Mezopotamya'nın Berbat İklimi. Bazı Kutsal İşaretler], 28 Ağustos 1916

34. Haber Başlı̆ğ: "Tigris Air Fights, The Good Weather Continuing, Mesopotamia", Aug., 25.

[Dicle Hava Mücadelesi. İyi Hava Devam Ediyor], Mezopotamya, 31 Ağustos 1916

35. Haber Başlığı: "A Morning in Court at Nasiriyeh, The British Subaltern as Judge, Nasiriyeh"

[Nasıriye'de Bir Sabah Oturum, Yargıç Olarak Bir İngiliz Teğmen], 6 Eylül 1916

36. Haber Başlığı: "A Welcome Change on the Tigris, Troops' Health Rapidly Improving”, Sept., 24.

[Dicle'de Hoş Geldiniz Değişimi, Birliklerin Sağlık Durumları Gelişiyor], 30 Eylül 1916

37. Haber Başlığı: "The Aeroplane in Mesopotamia, Machine-Gun Attacks on Enemy Cavalry", At the Front, Basra, Oct.26.

[Mezopotamya'da Bir Uçak, Düşman Piyadesi üzerine makinalı Silah Saldırısı], 2 Kasim 1916

38. Haber Başlığı: "The Fighting Indian in the Field. Contingents of Four Minor States".

[Sahada Hint Birliklerinin Mücadelesi. Dört Küçük Eyaletin Askeri Birlikleri], 12 Aralik 1916

39. Haber Başlığı: "Above the Mirage, Air Fighting in Mesopotamia. Harrying Irregulars and Thieves". Mesopotamia, 19 Aralı 1916

[Serabın Üzerinde, Mezopotamya'da Hava Muharebesi, Yağmacı Kaçaklar ve Hirsızlar, 19 Aralık 1916

40. Haber Başlığı: "Kut Advance, by Perfectly Timed Operations. Fine Work by Cavalry and Airmen", Near Kut,

[Kut İlerleyişi Mükemmel Zamanlamalı Operasyonlar, Piyadeler ve Havacılar], 23 Aralik 1916

41. Haber Başlığı: "Christmas on the Tigris, Airmen's Exploits. Break in the Weather", Dec.26, Tigris Front.

[Dicle'de Christmas, Havacıların Kahramanlığı, Havanın Kırılması], 2 Ocak 1917 
42. Haber Başlı̆̆ı: "Celts of the Indian Army, The Khattaks. Story of the Wounded Shere Ali”

[Hindistan Ordusunun Keltleri, Khattak'ları. Yaralı Shere Ali’nin Hikâyesi], 11 Ocak 1917

43. Haber Başlığı: "The Mesopotamian Fly, Mr. Candler in a New Rôle. Waging War on the Soldier's Rest"

[Mezopotamya Uçuşu, Mr. Candler Yeni Rolü, Askerlerin Dinlenmesine Savaş Açmak], 12 Ocak 1917

44. Haber Başlığı: "The Kut Success, British Casualties Slight”, Sinn Jan.9

[Kut İlerleyişi, İngiliz Kayıpları Hafif], 15 Ocak 1917

45. Haber Başlığı: "The Last Attack, Turks Escape by Clever Ruse”, Sinn, Jan, 19.

[Son Saldırı, Türkler Zekice Numara ile Kurtuldu], 27 Ocak 1917

46. Haber Başlığ1: "Western Front Tactics at Kut, Defensive More Costly than Attack", Shatt-el-Hai, Jan.27.

[Kut'ta Batı Cephesi Taktikleri, Savunma Saldırıdan daha Maliyetli], 31 Ocak 1917

47. Haber Başlı̆̆ı: "Operations at Kut, Advance from the Liquorice Factory", Tigris Cephesi, Feb. 10.

[Kut'ta Operasyonlar, Meyankökü Fabrikasından İlerleyiş̧], 15 Şubat 1917

48. Haber Başlığı: "Looking Ahead in Mesopotamia, Preparations for the Dog-Days. Ice Plant and Soda Water", Sinn, Jan.1.

[Mezopotamya'da İleriye Bakış, En Sıcak Günlere Hazırlık. Buzhane ve Sodalı su], 20 Şubat 1917.

49. Haber Başlı̆̆: "The Tigris Battle, How the Dahra Loop Was Won. Break in the Weather", Tigris Cephesi, Feb. 15.

[Dicle Muharebesi. Dahra Düğümü Nasıl Çözüldü. Havada Kırılma], 21 Şubat 1917

Issue 1

February

2020

50. Haber Başlığı: "The Crossing of the Tigris. Turks Completely Surprised".

[Dicle'yi Geçmek. Türkler Tamamen Şaşkın], 1 Mart 1917

51. Haber Başlığı: “The Tigris Pursuit, Two Stiff Rearguard Actions. Army's Cheers for Fighting Gunboats, A Gunboat on the Tigris, West of Shumran"

[Dicle Takibi. İki sert Geri Çekiliş Hareketi. Ordunun Savaş Botlarını Cesaretlendirmesi] 6 Mart 1917

52. Haber Başlığı: "Describing the Tigris Advance, Work of Navy, Airmen, and Cavalry, A Dadly Pursuit, A Gunboat on the Tigris", Near Dialah river, March 8.

[Dicle İlerleyişini Tanımlama, Donanma, Hava kuvvetleri ve Süvarinin Çalışması, Ölümcül Takip, Dicle'de bir Bot], Diyale Nehri yakını, 15 Mart 1917

53. Haber Başlığı: "In Baghdad, Unbounded Relief of Populace. Looting and Robbery Stopped, Baghdad", March 11,

[Bağdat'ta. Halkın Sınırsız Yardımı. Yağma ve Hırsızlık Durdu],16 Mart 1917

54. Haber Başlığı: "By River to Baghdad, The Work of our Gunboats, A Tight Corner". Azizie, March 3.

[Nehirle Bağdat'a. Savaş gemilerimizin Faaliyeti. Zorlu Bir Dönemeç], 22 Mart 1917

55. Haber Başlığı: "The Battle for Baghdad, Lancashire Men's Heroism. Forcing of te Dialah", Baghdad, March 12.

[Bağdat İçin Çarpışma, Lancashire'ın Askerlerinin Kahramanlığı. Diyale'nin Zorlanmas1], 26 Mart 1917

56. Haber Başlığı: "Pursuit of Turks in Mesopotamia, Four Lines of Advance", Under Jebel Hamrin, April 1.

[Mezopotamya'da Türklerin Takibi, Dört Hattın İlerleyişi], 9 Nisan 1917 
57. Haber Başlığı: "Foundation of our Tigris Triumph. The Hard Fighting Before Kut. Turkish Stubbornness", Mesopotamia, Feb.20.

[Dicle Zaferimizin İnşası. Kut’tan Önce Sıkı Çatışma. Türk İnad1], 10 Nisan 1917

58. Haber Başlığı: "Story of Turks' Flight from Persia. A Bare-Footed Army", April 2. [Türklerin İran'dan kaçışının Hikayesi. Çıplak Ayaklı Bir Ordu], 12 Nisan 1917

59. Haber Başlığı: "Turkish Armies in Movement, Far-Reaching Results of Kut”, Baghdad, April 6.

[Türk orduları harekette, Kut'un Geniş Kapsamlı Sonuçları], 17 Nisan 1917

60. Haber Başlı̆̆ı: "A Victory in Intense Heat, Baghdad”, April 19.

[Yüksek Sicaklikta bir Zafer], 28 Nisan 1917

61. Haber Başlığı: "Baghdad Railway Section, Turks' Desperate effort to Save he Terminus", Baghdad, April 24.

[Bağdat Demiryolu Hattı, Son İstasyonu korumak için Türklerin Umutsuz Çabası], 1 Mayis 1917

62. Haber Başlığı: "Dashing Attack in Mesopotamia, Complete Surprise for the Turks", Baghdad, May 2.

[Mezopotamya'da Cesur Atak, Türkler için tam bir Sürpriz], 8 Mayıs 1917

63. Haber Başlığı: "Things Seen in Baghdad, Strange advantures of a Soldier of France", [Bağdat'ta görülen Şeyler. Fransa'nın askerlerinin Tuhaf Serüvenleri],15 Mayıs 1917

64. Haber Başlığı: "Tigris Campaign Since Baghdad, All Main Objects Realized", Baghdad, May. 10.

[Bağdat'tan itibaren Dicle Seferi. Tüm temel hedefler gerçekleştirildi], 23 Mayıs 1917

65. Haber Başlığı: "The Model Coolie in Mesopotamia, Recruits from an Indian Utopia". The Simple Santral, Baghdad.

[Mezopotamya'daki Hamal, Hintli bir Ütopyadan Asker Yazımı], 20 June 1917

66. Haber Başlığı: “The Armenian Tragedy, Refugees' Stories in Baghdad, Wholesale Massacres”, Baghdad, April.

[Ermen Trajedisi, Göçmenlerin Bağdat'taki Anlatıları, Toplu Katliam], 21 June 1917

67. Haber Başlığı: "Turkish Tyranny, Treatment of Subject Races in Baghdad”, Baghdad, May.

[Türk Tiranlığı, Bağdat’taki Halkın Tedavisi], 22 June 1917

68. Haber Başlığı: "Amphibious Warfare, The Navy’s Early Work in Mesopotamia", [Amfibi Harekat1, Ordunun Mezopotamya'daki Öncü Faaliyetleri], 26 Temmuz 1917.

69. Haber Başlığg: "The Super-Cavalry on the Tigris. Navy's Aid to General Townshend". [Dicle'de Müthiş Süvari. Ordunun General Townshend'a Yardımı], 28 Temmuz 1917.

70. Haber Başlı̆̆1: "Battered Warboots on the Tigris, Navy's Rearguard Work".

[Dicle'de Yıpranmış Savaş botları, Donanmanın Artçı Faaliyeti], 30 Temmuz 1917.

71. Haber Başlığı: "Hottest Known Season in Mesopotamia, The Inevitable Football", Baghdad, Sep.15.

[Mezopotamya'da Bilinen En Sıcak Mevsim. Kaçınılmaz Futbol] 19 Eylül 1917

72. Haber Başlığı: "Post Reduced by Airmen, Turkish Garrison Taken on the Euphrates", Baghdad, Sept. 21.

[Havacının Bıraktığı Bildirge. Fırat'ta Üstlenen Türk Garnizonu], 25 Eylül 1917

73. Haber Başlığı: "Battle of Ramadie Described, The Turks Concerned, A Brillant Manoeuvre". Ramadie, Sept. 29.

[Ramadiye'de Muharebesini Tasviri. Türkler Toplandı, Parlak bir Menavra], 8 Ekim 1917

74. Haber Başlı̆̆ı: "Disorderly Retreat from Ramadie, The Trapping of the Turks", Ramadie, Sept, 30. 
[Ramadiye'den Düzensiz Çekiliş. Türklerin Tuzağa Düşüşü], 11 Ekim 1917

75. Haber Başlığı: "How Tekrit was Won, Charge by Hussars and Indian Lancers", Tekrit, Nov.6,

[Tikrit Nasıl Kazanıldı. Hussars ve Indian Lancer'ların Taarruzu],15 Kasım 1917

76. Haber Başlığı: "Disinterred Babylon, Forgotten Glories of City of Nebuchadnezzar"

[Babylon'un Açığa Çıkması. Nebuchadnezzar şehrinin kahramanları], 8 Aralık 1917

77. Haber Başlığı: "The Advance East of Baghdad, Driving the Turks from The Hills, Five miles North of Kara Tepe", Dec. 6.

[Bağdat Doğusuna İlerleyiş, Hill'den Türklerin Sürülmesi. Kara Tepe Kuzeyinden 5 mil uzaklıkta], 13 Aralık 1917

78. Haber Başlığı: "Severe Mesopotamian Winter, Cholera Danger Over", Baghdad, Dec. 14.

[Korkunç Mezopotamya Kışı, Kolera Tehlikesi Geçti], 24 Aralık 1917

79. Haber Başlığı: "The Euphrates Victory, How the Turks were Beaten. A Dramatic Surrander", Wadi Hauran (Euphrates), March 27.

[Fırat Zaferi. Türkler Nasıl Mağlup Edildi. Dramatik bir Teslimiyet], 12 Nisan 1918.

80. Haber Başlığı: "Prosperity on the Euphrates, 'Record' Harvest Expected, A Great Year's Work"

[Fırat'taki Zenginlik. Rekor Hasat Beklenmekte. Bir Büyük Yılın Çalışması], 1 Mayıs 1918

81. Haber Başlığı: “The Victory on the Mosul Road. Gen. Marshall's Enveloping Tactics", Tuz Khurmatl, May 1.

[Musul Yolunda Zafer. General Marshall'ın Kuşatma Taktikleri. 20 Mayıs 1918.

82. Haber Başlığ1: "On the Heels of the Turks, The Enemy Flight Towards Mosul", Kirkuk, May 7.

[Türklerin Topuğunda, Musul'a Doğru Düşman Kaçış1], 24 Mayıs 1918

83. Haber Başlığı: "Mesopotamia As a Granary, Developments all over the Country", Baghdad, May 18.

[Tahıl Ambarı olarak Mezopotamya, Tüm Ülkedeki Gelişmeler], 27 Mayıs 1918

84. Haber Başlığı: "Outflanking the Turks. Last Advance on the Mosul Road", Baghdad, May 11.

[Türklerin Kuşatılması, Musul Yolundaki Son İlerleyiş], 27 Mayıs 1918

85. Haber Başlığı: "The Dirties Town of Asia. Bitumen Wells of Hit"

[Asya'nın En Kirli Kasabası. Katran/Bitüm Kuyuları Vuruldu], 28 Mayıs 1918

86. Haber Başlığı: "Transformation of Baghdad, A Year of British Rule".

[Bağdat'ın Dönüşümü. Bir Yıllık İngiliz Yönetimi], 2 Temmuz 1918. 
Ek 2:

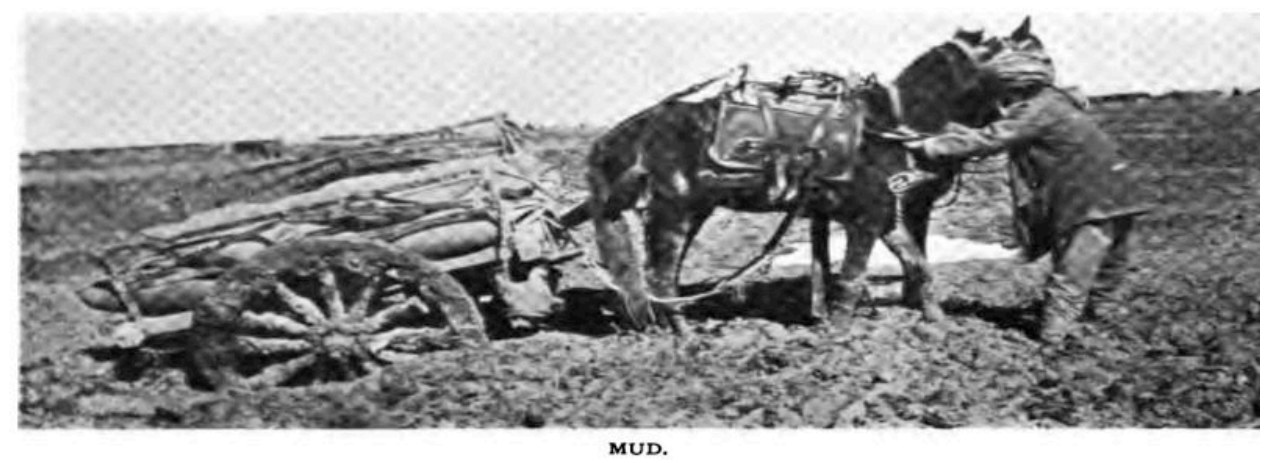

Kaynak: Candler, a.g.e., s. 99.

Ek 3:

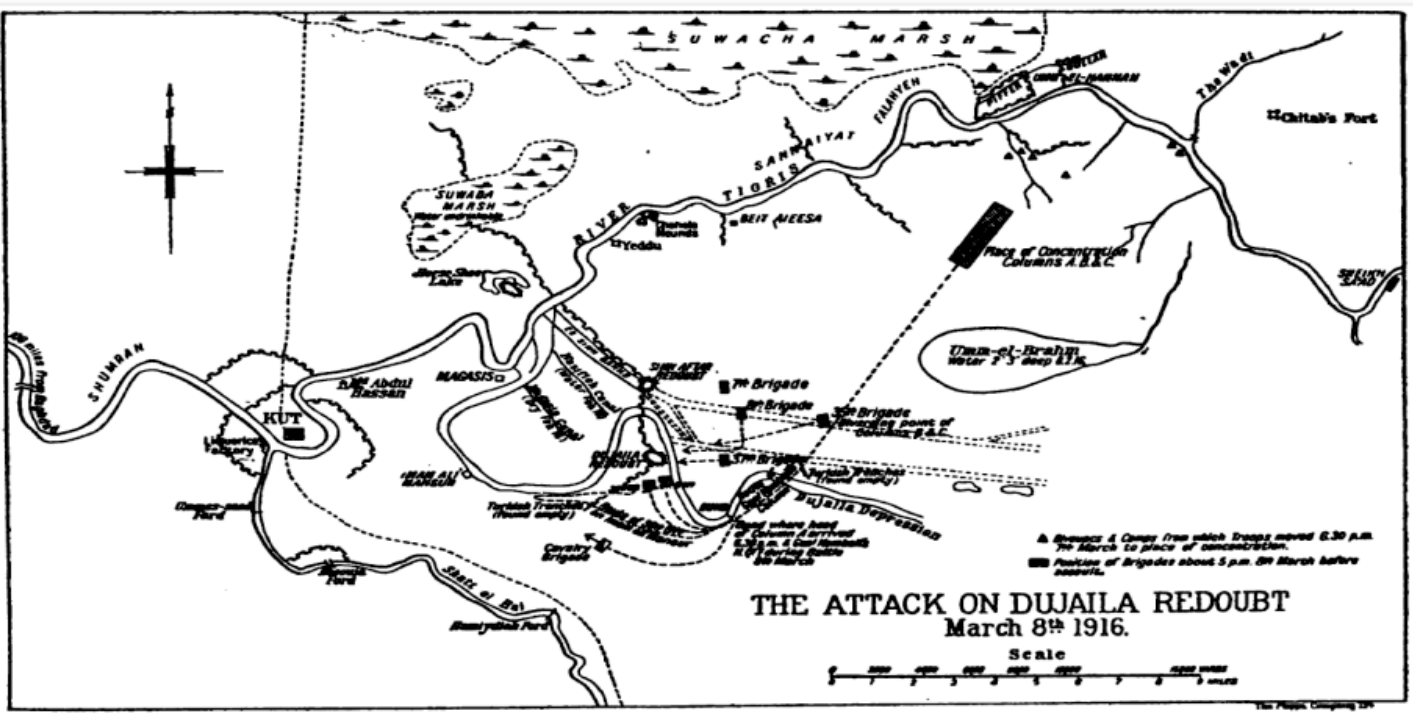

Volume 12

Issue 1

February

2020

Kaynak: Candler, a.g.e., s. 141. 
Ek 4:

버 SISTORY

283

Volume 12

Issue 1

February 2020

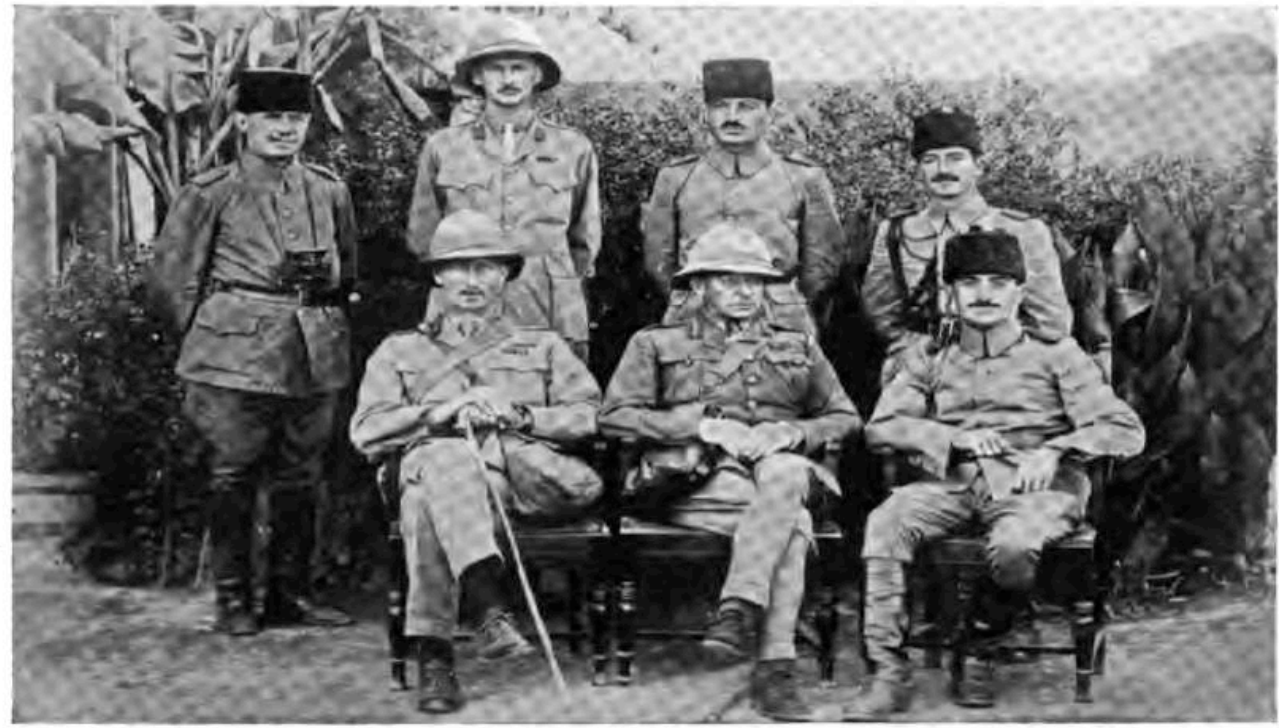

AFTER THE FALL OF KUT: GENERAL TOWNSHEND With KHALIL PASHA (on the right).

Kaynak: Candler, a.g.e., s. 212.

Ek 5:

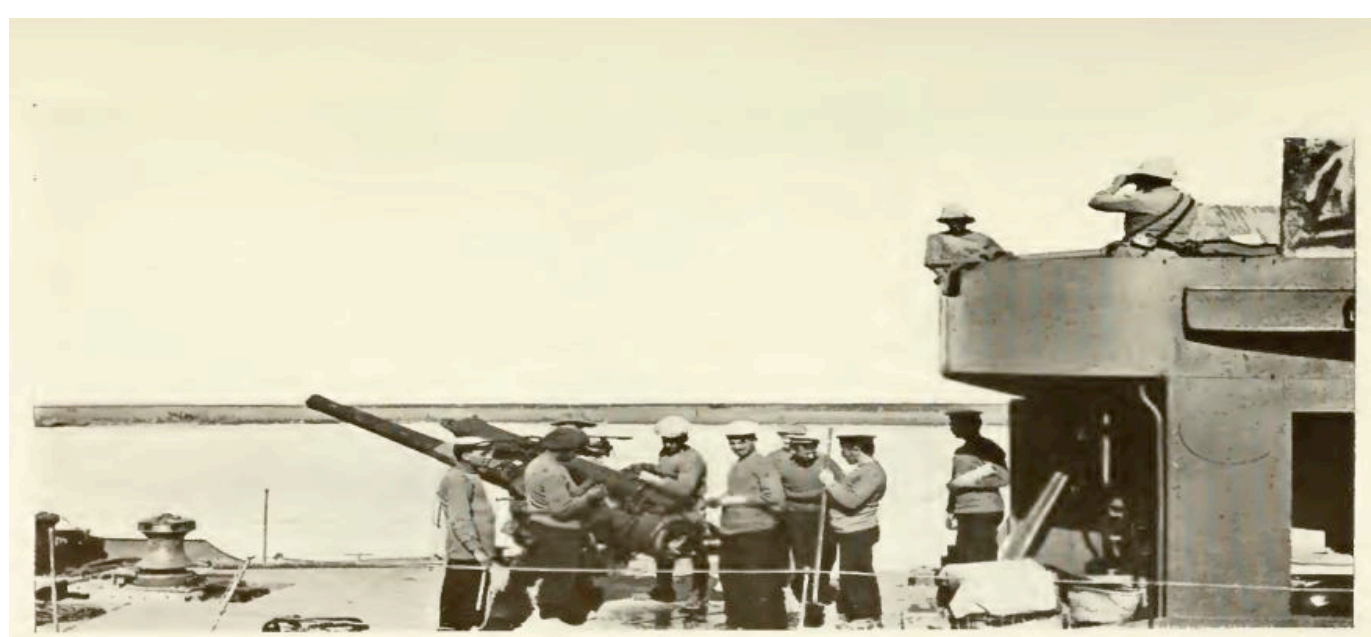

GUNBOAT ON THE TIGFIS.

Kaynak: Candler, a.g.e., s.73. 